Article

\title{
Past Experience and Willingness to Pay: A Comparative Examination of Destination Loyalty in Two National Parks, China
}

\author{
Jianqiong Yuan ${ }^{1}$, Jingjing Li ${ }^{1, *}$, Jinyang Deng ${ }^{2, *}$ and Douglas Arbogast ${ }^{3}$ \\ 1 College of Tourism, Central South University of Forestry \& Technology, Changsha 410004, China; \\ T20081193@csuft.edu.cn \\ 2 Recreation, Parks, \& Tourism Resources Program, School of Natural Resource, West Virginia University, \\ Morgantown, WV 26506, USA \\ 3 Family and Community Development, WVU Extension Service, West Virginia University, Morgantown, \\ WV 26505, USA; douglas.arbogast@mail.wvu.edu \\ * Correspondence: T20071151@csuft.edu.cn (J.L.); jinyang.deng@mail.wvu.edu (J.D.); \\ Tel.: +1-304-293-6818 (J.D.)
}

Citation: Yuan, J.; Li, J.; Deng, J.; Arbogast, D. Past Experience and Willingness to Pay: A Comparative Examination of Destination Loyalty in Two National Parks, China. Sustainability 2021, 13, 8774. https:// doi.org/10.3390/su13168774

Academic Editors: Brian Garrod and Kyle Maurice Woosnam

Received: 23 June 2021

Accepted: 29 July 2021

Published: 5 August 2021

Publisher's Note: MDPI stays neutral with regard to jurisdictional claims in published maps and institutional affiliations.

Copyright: (c) 2021 by the authors. Licensee MDPI, Basel, Switzerland. This article is an open access article distributed under the terms and conditions of the Creative Commons Attribution (CC BY) license (https:// creativecommons.org/licenses/by/ $4.0 /)$.

\begin{abstract}
The long-term sustainability of China's national parks depends on the appropriate use and management of park resources and the provision of positive experience opportunities for tourists. While past experience, in terms of frequency of visits to the same destination and behavioral intention measured as willingness to revisit/recommend, have been extensively examined in a typical destination loyalty model using structural equation modeling (SEM), past experience with other destinations and willingness to pay (WTP), another form of behavioral intention, have received less attention from researchers. This paper, for the first time, simultaneously examined these two types of past experience and WTP using both second-order and first-order SEMs, based on data collected from two national parks in China. Results show that, while frequency of visits had no significant impacts on attribute satisfaction (AS) nor on overall satisfaction (OS), previous experience with other destinations significantly influenced AS, which, in turn, significantly predicted OS. While OS significantly and consistently predicted visitors' intentions to revisit/recommend for both samples, its impact on WTP was significant for one sample, but not for the other. This suggests that asymmetric beliefs in destination loyalty may exist, depending on how and where behavioral intention was measured. The study endorses norm theory in studying destination satisfaction.
\end{abstract}

Keywords: behavioral intention; norm theory; entrance fees; satisfaction; ecotourism; SEM; WTP

\section{Introduction}

As important nature-based tourism destinations, national parks play an essential role in the protection of natural resources, as well as provision of recreational, educational, and spiritual opportunities for the public. Thus, the long-term sustainability of national parks depends on the appropriate use of the park resources and the provision of positive experience opportunities for tourists.

In the context of China, current practice regarding national parks is focused on the economic aspect of the triple bottom line of sustainability, with entrance fees being the major source of tourism revenues [1]. Due to the reliance on entrance fees for revenue generation, it is possible that some tourism destinations and popular national parks have inflated entrance fees to the point that it is having a negative affect on the visitor experience. This so called 'tickets economy' model based on entrance fees "has caused excessive exploitation of tourism resources, and thus, it does not conform to the sustainable development principles" [1] (p. 263). It should be noted that tourists tend to become less loyal if they are not satisfied with their visiting experience at a destination, resulting in less 
revenue from tourism. Therefore, national parks should seek to provide quality products and services for tourists, which, in turn, may contribute to destination loyalty.

Visitors' loyalty to a destination is a function of numerous factors. In a typical destination loyalty model, variables such as motivation, expectation, destination image, service quality, perceived values, and overall satisfaction are commonly examined using structural equation modeling (SEM), while two other variables: past experience with other destinations and willingness to pay (WTP) have received less attention.

Past experience can refer to the frequency of visits to the same destination (e.g., first time visitors vs. repeat visitors) or previous experience with other destination(s) (e.g., positive vs. negative). While past experience in terms of frequency of visits has been extensively investigated in the literature [2-7], studies on past experience with other destinations are limited. It is very likely that visitors evaluate their experience with the current destination using their previous experiences with other destinations as reference points [8]. In other words, "the difference between present and past experiences can be a norm used to evaluate tourist satisfaction" [8] (p. 48). Thus, visitors' satisfaction can be assessed by comparing their current travel destination with similar destination(s) visited previously via the norm theory [9].

Behavioral intention in a destination loyalty model can also be measured by two dimensions: revisit intention/word of mouth and/or willingness to pay (WTP) [10]. While revisit intention and word of mouth have been extensively examined in almost all SEM studies on destination loyalty, only a few have included WTP [11-14] in a SEM model, despite the fact that WTP may be more pertinent than revisit intention/word of mouth to reflect a visitor's loyalty to a destination as it is directly linked to the monetary value of the destination's products/services. Therefore, it deserves more research.

Given the lack of research on past experience with other destination(s) and WTP, this paper, for the first time, examined the two variables simultaneously in a destination loyalty model. It did so by including three other variables-motivation, attribute satisfaction (AS), and overall satisfaction (OS), based on data collected from two nature-based tourism destinations in China: Lushan National Park $\left(29^{\circ} 26^{\prime} 0^{\prime \prime} \mathrm{N}, 115^{\circ} 52^{\prime} 0^{\prime \prime} \mathrm{E}\right)$ and Zhangjiajie National Forest Park $\left(29^{\circ} 9^{\prime} 39^{\prime \prime}\right.$ N, $110^{\circ} 24^{\prime} 58^{\prime \prime}$ E) (Figure 1). The two national parks were chosen for two reasons. First, both parks are top ecotourism destinations in China, ranked at the $5 \mathrm{~A}$ level, the highest ranking of tourism scenic areas and attractions in the country. They are also listed as UNESCO world geological parks and world heritage sites for their unique geological formations and mountain-based natural scenery dotted with rich cultural and historical attractions (Figure 2). Thus, the two parks can provide visitors with a similar nature-based tourism experience. Second, as with most of China's other parks, both parks charge entrance fees, which are usually higher. This is particularly true for Zhangjiajie national forest park, which was ranked the third most expensive park in China in terms of entrance fees [15]. This justifies the inclusion of WTP in the SEM models. It would be interesting to see how much visitors are willing to pay compared to how much they have actually paid. An examination of WTP in a destination loyalty model can reveal if the entrance fee for a national park is acceptable or not from the tourists' perspective. Each destination was examined using a second-order SEM, which was then compared with a first-order SEM, whereas factor means obtained from a factor analysis were used in the model $[8,16,17]$.

This research is guided by the following questions:

(1) Which past experience (frequency of visits or experience with other destinations visited) best predicts AS and OS?

(2) Which park's entrance fee is more reasonable and acceptable?

(3) Can the magnitudes and signs that represent the relationship between any two variables in a SEM be cross validated by the two samples?

(4) Are the magnitudes and signs that represent the relationship between any two variables comparable across models? 


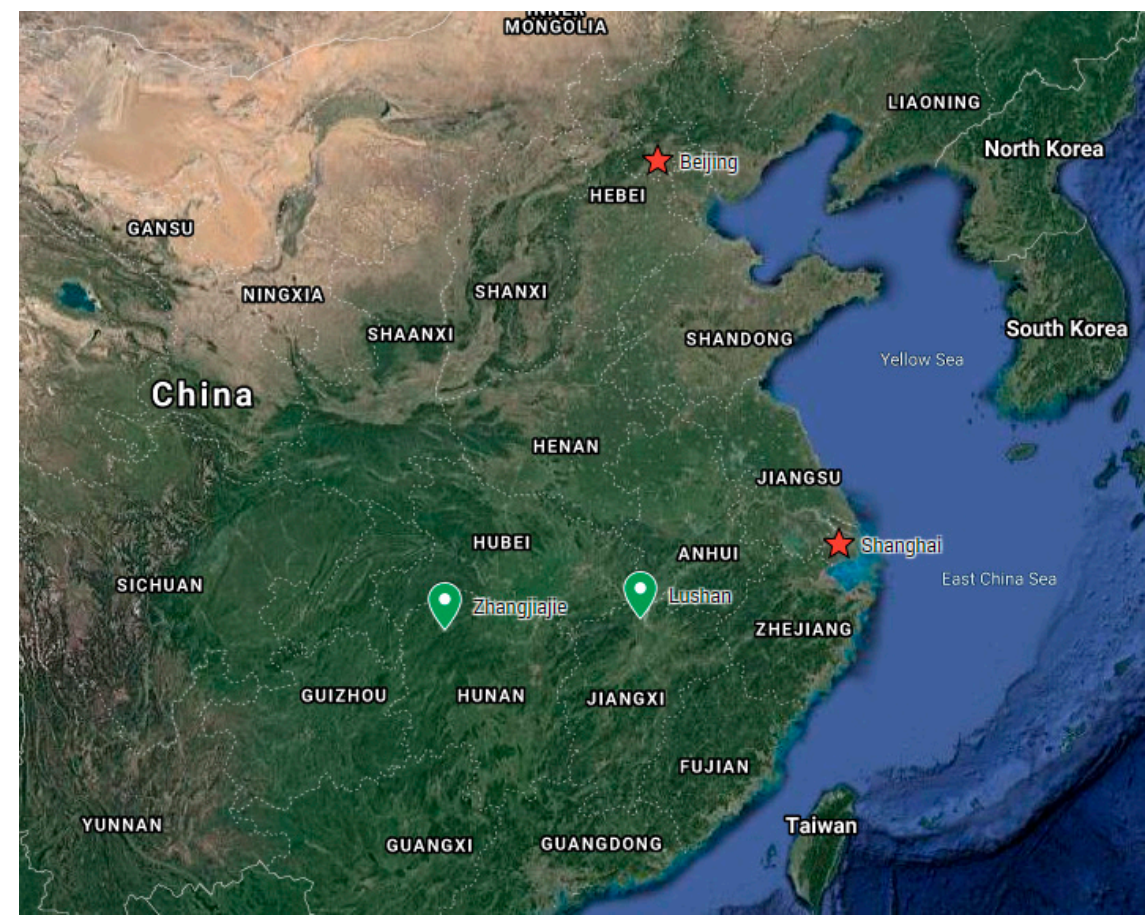

Figure 1. Locations of the two parks.

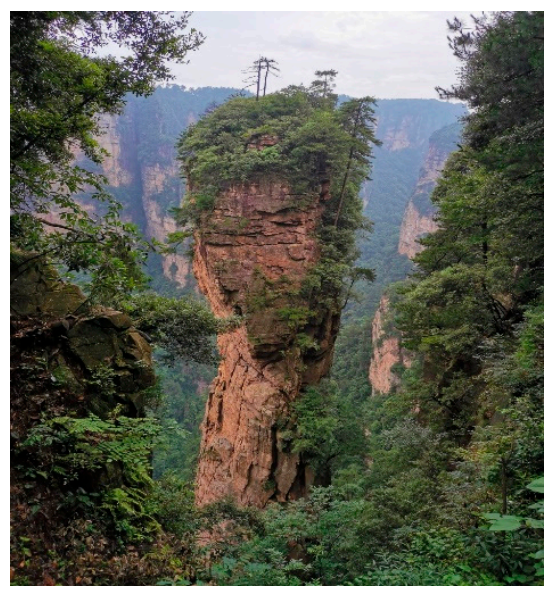

Zhangjiajie

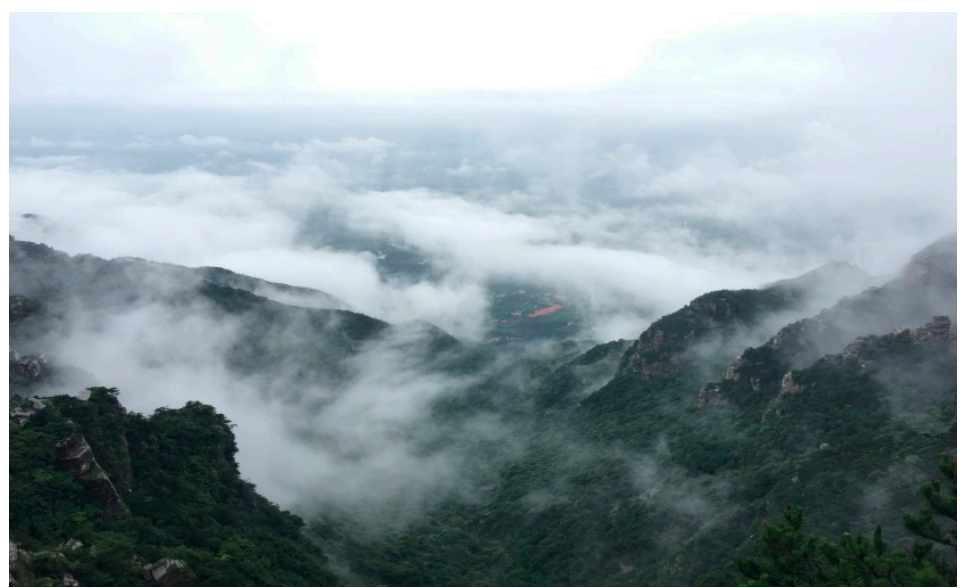

Lushan

Figure 2. A glimpse of the two parks. (Courtesy: Jianqiong Yuan and Shuangquan Zhang).

\section{Literature Review}

2.1. Past Experience, Satisfaction, and Destination Loyalty

Past experience, in terms of frequency of visits to the same destination (i.e., first timers vs. repeaters), has been widely examined in the tourism literature, but with mixed findings [18]. For example, while first timers were found in some studies to be significantly less satisfied and/or less loyal than repeaters [3,4,6,7,11,18-22], the opposite was true in some other studies $[19,23,24]$. Still, others found no significant differences in satisfaction or loyalty between first timers and repeaters [25-28].

Explanations for the difference in satisfaction and loyalty between first timers and repeaters vary. Intuitively, people will be unlikely to revisit a destination if they did not feel satisfied with their previous visit experience [6], implying repeaters tend to be more satisfied. However, some argue that repeaters are less likely to be satisfied than first timers because they tend to have a higher expectation from their previous experience [24]. As a result, negative disconfirmation between outcomes and expectations may occur for 
repeaters more often than for first timers, resulting in less satisfaction. A study [26] found that "an additional visit to [a location] can worsen the judgment on satisfaction" (p. 15). This, to some extent, is conceptually aligned with the "Law of Diminishing Marginal Utility" proposed by 19th century German economist H.H. Gossen [29]. That is, there may be a diminishing satisfaction with additional visits to the same destination. As a result, past experience can be a 'double edged sword' with both favorable and unfavorable effects on satisfaction.

It should be noted that there are many other factors that may influence satisfaction/loyalty differently for first timers and repeaters, including the visitors' relationship with service providers, other customers, and group members [30], self-congruity [31], sensory impressions [32], length of stay [26], and destination attributes [28,33], among others.

There is no doubt that if tourists are more satisfied with their experience in a destination, they would be more likely to revisit or recommend it to others. However, satisfaction may not be the only reason for an individual to revisit the same destination [18], other factors such as availability of substitutes with similar characteristics or distance to travel [34], perceived risk and safety [35-37], familiarity [38-40], group composition [25], and experience with other destinations may also affect the likelihood of an individual to revisit a destination [41]. For example, in terms of past experience with other destinations, a study [8] found that positive comparison with other similar places visited is positively related to OS which further leads to destination loyalty. Another study [41] also examined the impact of previous travel experience on satisfaction, whereas the number of countries travelled before, instead of experience comparison with the current destination, was used in this study. Despite this, past experience measured by the number of countries visited previously was also found to be positively related to destination loyalty.

\subsection{Motivation, Satisfaction, and Loyalty}

People often seek to visit their preferred destinations to pursue their favorite activities and to realize their desirable experiences [42,43]. Thus, activities pursued and experiences realized are conceptually rooted in the motivation that drives people to travel. Motivation is defined as a "state of need, a condition that exerts a push on the individual towards certain types of action that are seen as likely to bring satisfaction" [44] (p. 16). Some researchers [45] argue that motivations determine people's behaviors as well as their expectations of products / services provided by a destination, while satisfaction "results from corresponding needs or motives being met" [46] (p. 66). Hence, the relationship between motivation and satisfaction has been "a popular research interest for many scholars" [47] (p. 201).

As with findings on the relationship between past experience (in terms of first timers vs. repeaters) and satisfaction being mixed, findings on the relationship between motivation and satisfaction are also somewhat inconsistent. Although most studies revealed a positive relationship between motivation and OS [47,48], there are also studies that found no significant relationship between the two variables $[49,50]$ or even that a significant negative relationship exists between them [8]. For example, the relationship between the pull travel motivations and OS was significantly negative while items measuring push motivations were positively related to OS [8]. That said, both the pull and push motivations were found to be significantly and positively related to tourists' OS in another study [51]. This may indicate that findings on the relationship between motivation and satisfaction are sample specific.

\subsection{Satisfaction and Willingness to Pay}

The examination of the relationships between satisfaction and WTP can be justified by the equity theory which "focuses on fairness in social exchange" [52]. That is, customers would be willing to pay more if they perceived "a high outcome of an exchange" (p. 85) from experiencing a high level of satisfaction. In the tourism literature, satisfaction as it relates to WTP has been examined using different statistical methods, including logit regression [53], the Tobit model [54], and SEM [11-14]. All of these studies except one [12] 
have reported a significant positive relationship between the two variables. Specifically, a study [53] on Annapurna conservation area, Nepal found that OS, along with two other trip characteristics - use of a guide and larger group size-had the most significant impact on visitors' willingness to pay higher entry fees to the area. Another study [54] found that "satisfaction with different characteristics of the destination exerts a positive effect also on the willingness to incur an expenditure within the different spending categories" (p. 16).

There are several other studies that either examined the relationship between satisfaction and expenditure or between WTP and service quality. For instance, one study [55], in examining the relationship between exhibition attendees' satisfaction and expenditure in China, found that a higher satisfaction level in "hotel, food, and attractions" as well as in "facilities" will lead to more spending. Another study [56] regressed customers' willingness to pay more for travel services on the five dimensions of the service quality measure [57], finding that the reliability, assurance, and tangibles had the greatest relationships with the willingness to pay more (although the relationship sign for tangibles was negative). Recently, a third study [54] reported that about a one-unit increase in satisfaction with the landscape leads to a $7.6 \%$ increase in total visitor spending and a one-unit increase in satisfaction with prices generates about a $7 \%$ increase in total expenditure.

\subsection{Attribute Satisfaction and Overall Satisfaction}

Satisfaction has been measured at the global and attribute level, namely, overall satisfaction and attribute satisfaction, with the former being "an overall evaluation based on the total purchase and consumption experience with a good or service over time" [58] (p. 54), and the latter being "the consumer's subjective satisfaction judgment resulting from observations of attribute performance" [59] (p. 421). A destination is composed of various individual attributes, which collectively affect OS [60]. Although OS has been the research focus in most previous studies, several studies have also examined the relationship between AS and OS using SEM, finding that AS significantly and positively predicts OS $[3,16,28,49,61]$.

In summary, the literature review outlined above clearly shows that, although findings are not always consistent from study to study, most studies support that motivation is an antecedent variable that predicts satisfaction, which, in turn, positively relates to WTP and loyalty. Previous studies also found repeaters tend to be more satisfied than first timers. In addition, satisfaction at the attribute level consistently predicts overall satisfaction, and positive experience in comparison with previous destinations visited is significantly related to satisfaction. Thus, the following nine hypotheses were proposed:

Hypothesis 1. A higher level of motivation will lead to a higher level of AS.

Hypothesis 2. A higher level of motivation will lead to a higher level of OS.

Hypothesis 3. Frequency of visits will be significantly and positively related to AS.

Hypothesis 4. Frequency of visits will be significantly and positively related to OS.

Hypothesis 5. Positive comparison with other destinations visited will lead to positive AS.

Hypothesis 6. Positive comparison with other destinations visited will lead to positive OS.

Hypothesis 7. AS will significantly and positively lead to OS.

Hypothesis 8. OS will be significantly and positively lead to loyalty.

Hypothesis 9. OS will be significantly and positively lead to WTP. 
To test these hypotheses in a robust way, this study, as aforementioned, collected data in two popular nature-based tourism destinations-Lushan National Park and Zhangjiajie National Forest Park-and tested the hypotheses with the two separate datasets in SEM models.

\section{Methods}

\subsection{Questionnaire and Measures}

A survey questionnaire was designed by drawing upon findings from the literature (Appendix A). The questionnaire was reviewed and approved for use by both the Lushan National Park Administration and Zhangjiajie National Forest Park Administration. This questionnaire collected information on tourists' trip characteristics (including past experience in terms of frequency of visits and past visitation to other similar destinations), motivation, attribute satisfaction, overall satisfaction, and destination loyalty. In addition, attribute importance was included in the Lushan questionnaire and attribute expectation was measured in the Zhangjiajie questionnaire. These two measures were not included in the SEM analyses for three reasons. First, there are conceptual and operational issues related to the use of attribute importance and/or attribute expectation in a model [62]. Second, for the sake of model simplicity, only variables measured in both parks are included in SEMs. However, the attribute expectation was still analyzed as an appendix (Appendix C) to support discussions on expectancy-disconfirmation theory vs. norm theory later in the discussion and conclusion section of this paper.

Travel motivation to each park was measured with 14 items adopted from the Recreational Experience Preferences (REP) [63], while 14 items were used to measure attribute satisfaction on natural/cultural resources, customer service, entrance fees, safety and security, shopping, food, and park management [64,65]. Overall satisfaction was measured by a single item: "I am satisfied with my overall experience with the park." The one item summative measure of overall satisfaction has been used in many other studies $[15,61,66,67]$. Finally, destination loyalty was measured by two dimensions: three commonly used items that reflect tourists' intentions to revisit the park [68] and their willingness to recommend it [69], and WTP, which was measured by one question: "if there are no entrance fees, how much would you be willing to pay to enter the park?" All items were measured using a 5-point Likert scale.

\subsection{Data Collection}

On-site, self-administered surveys were conducted in August 2017 in Lushan National Park and August 2018 in Zhangjiajie National Forest Park. Surveys were administered onsite by three faculty members and undergraduates using the convenience sampling method. Sampling sites were chosen based on previous studies where tourists were found to stay longer $[70,71]$ and were willing to help with minimum disturbance of their tourism experience.

Surveys were carried out at the exit of each site selected. Prospective respondents were approached by the survey administrators in a way that they first introduced themselves and explained the purpose of the study to the respondents. If a visitor was unwilling to participate, then the next one available was approached [72]. During the survey, the surveyors (faculty/students) were present around the participants when they were filling out the questionnaire, ready to answer any questions concerning the questionnaire and/or the parks.

\subsection{Data Analysis}

Data were screened prior to data analysis. For the Lushan sample, of the 548 questionnaires collected, 33 were deleted due to skeptical responses or systematical missing data, resulting in 515 for further analysis. For the Zhangjiajie sample, 17 out of 577 cases were removed for similar reasons. This reduced the sample size to 560 for further analysis. After data screening, the missing rate for both samples is less than $2 \%$ for all observed 
variables that measure motivation, attribute satisfaction, destination loyalty, and overall satisfaction, which is considered inconsequential [73]. These missing data were then imputed using the expectation-maximization algorithm [74]. In addition, data skewness and kurtosis for these observed variables were also tested. The normality assessment indicates that the absolute values of all of these variables are less than two and three for skewness and kurtosis, respectively (Appendix B), suggesting the data can be considered not to "extremely" deviate from the normal distribution [75], and are thus appropriate for SEM analysis. To increase estimate accuracy, the maximum likelihood bootstrapping technique with 10,000 bootstraps was used [76].

Data analysis consisted of four steps and was conducted using SPSS 26 and AMOS 26. First, EFA was conducted of the Lushan data and Zhangjiajie data separately, using principal components analysis with varimax rotation. An eigenvalue of 1.00 or more was used to identify factors. This study's sample size falls within the best range $(>500)$ for factor analysis [77].

The appropriateness of the data for factor analysis was tested using the Kaiser-MeyerOlkin (KMO) measure of sampling adequacy and Bartlett's test of sphericity. A cut-off point of 0.50 was used to determine items for a factor [78], whereas a loading difference of 15 was used to detect and separate cross loadings [79,80]. In addition, the Cronbach's alpha value of 0.70 [81] was used as the threshold for measuring a factor's reliability.

Second, the measurement model for each sample was tested using confirmatory factor analysis (CFA). Although some researchers [82] recommended a two-stage factor analysis for SEM, with one sample for EFA and another sample for CFA, which further confirms the factor structure obtained from EFA for the first sample, this two-stage approach was not followed in this study due to factor patterns being different between the two samples.

The construct's reliability and validity were assessed using three parameters: composite reliability (CR), average variance extracted (AVE), and maximum shared variance (MSV). A construct is considered to have a good internal consistency if CR $>0.70$, a good convergent validity if AVE > 0.5, and a good discriminant validity if AVE > MSV [83].

Third, a second-order SEM was built for the Lushan sample and the Zhangjiajie sample, respectively, to examine the relationships among past experience, motivation, attribute satisfaction (AS), overall satisfaction (OS), and loyalty (intention to revisit/word of mouth and WTP), with past experience (frequency of visits and visitation with other destinations) and motivation as antecedent variables. Finally, first-order SEMs that used the means of factor items were examined and compared with the second-order SEMs.

The model fit was assessed using $\chi^{2} / d f$ (the ratio of $\chi^{2}$ value over the degree of freedom) and other indices such as RMSEA (Root Mean Square Error of Approximation), CFI (Comparative Fit Index) and IFI (Incremental Fit Index). Specifically, a $\chi^{2} / d f$ ratio up to five is considered acceptable and less than three indicates a better fit [84]. An RMSEA less than 0.05 indicates a better fit, between 0.05 to 0.10 a fair fit, and greater than 0.10 a poor fit [85]. While CFI or IFI is commonly accepted to be greater than 0.90 , and a value of 0.95 is considered as a better fit [86], a more liberal cutoff of 0.80 is also acceptable [87]. In fact, some studies have reported a value between 0.80 and 0.90 [8,88-90].

\section{Results}

\subsection{Response Rate}

Of the 750 questionnaires distributed in Lushan, 548 were collected, resulting in a response rate of $73.1 \%$, which is comparable to the response rate of $76.9 \%$ in Zhangjiajie where 577 out of 750 visitors were willing to take the survey.

\subsection{Socio-Demographic Characteristics and Trip Information}

The socio-demographic characteristics and trip information for both samples are similar. Interestingly, the two samples consisted of exactly $53.1 \%$ females and $46.9 \%$ males. Most respondents were young, with the age group 18-24 accounting for $41.2 \%$ for Lushan and $38.4 \%$ for Zhangjiajie, respectively. The majority of participants (60.1\% for Lushan vs. $63.5 \%)$ 
had a university/college degree and were less affluent with $44.3 \%$ of them for Lushan (vs. $42.4 \%$ for Zhangjiajie) having an annual income below $¥ 12,000$ (approximately $\$ 1864$, at the rate of $\$ 1=¥ 6.48,11$ July 2021 . This rate applies throughout this paper). In addition, approximately three-quarters of the participants were first timers $(72.9 \%$ for Lushan vs. 79.0 for Zhangjiajie). In terms of WTP, visitors were willing to pay an average of $¥ 130$ (approximately $\$ 20.1$ ) to enter Lushan (vs. the entrance fee of $¥ 111$, approximately $\$ 17.1$ for Zhangjiajie), compared to the actual entrance fee of $¥ 180 \mathrm{RMB}$ for Lushan (approximately $\$ 27.8$ ) and $¥ 248$ RMB (approximately \$38.3) for Zhangjiajie at the time of the surveys.

\subsection{EFA for Factors}

Tables 1 and 2 present the EFA results on motivation for Lushan and Zhangiajie, respectively. Each sample generated three factors: fitness and relaxation, authentic experience, and nature affinity for Lushan and nature affinity and relaxation, authentic experience, and fitness and wellbeing for Zhangiiajie. Cronbach's alpha value for each factor is greater than 0.70 ranging from 0.71 to 0.83 for Lushan and 0.74 to 0.87 for Zhangjiajie, indicating a good construct reliability.

Tables 3 and 4 present the EFA results on AS for the two study areas, respectively. While three factors-tourism resources, service quality, and park management-were extracted from the Lushan sample, two factors-tourism resources, and service quality and park management-were derived from the Zhangjiajie sample. As with motivation factors, Cronbach's alpha value for each AS factor is greater than 0.70 ranging from 0.71 to 0.87 for Lushan and 0.77 to 0.88 for Zhangjiajie, indicating a good construct reliability, too.

Table 1. Summary results of exploratory factor analysis for motivation (Lushan, $n=515$ ).

\begin{tabular}{ccccc}
\hline & Factor (Proportion): & \multicolumn{3}{c}{ Factor } \\
\cline { 3 - 5 } Code & Scale Name \& Items & $\mathbf{1}$ & $\mathbf{2}$ & $\mathbf{3}$ \\
& Fitness and relaxation (L_MO3) & & \\
Factor 1 & Fitness & 0.701 & 0.092 & 0.358 \\
M3 & Adjust life & 0.681 & 0.182 & 0.316 \\
M4 & Be away from daily lives & 0.761 & 0.216 & 0.033 \\
M10 & Rest and relaxation & 0.780 & 0.114 & 0.070 \\
M11 & Mental and physical health & 0.637 & 0.268 & 0.034 \\
M12 & Authentic experience (L_MO2) & & & \\
Factor 2 & Seek adventurous experience & 0.175 & 0.697 & -0.055 \\
M6 & Experience new things & 0.286 & 0.694 & 0.101 \\
M7 & Experience local customs and culture & 0.123 & 0.779 & 0.230 \\
M8 & Understand the park's history & 0.191 & 0.698 & 0.223 \\
M9 & Nature affinity (L_MO1) & & & \\
Factor 3 & Close to nature & 0.137 & 0.103 & 0.789 \\
M1 & Nature observation & 0.183 & 0.183 & 0.740 \\
M2 & Eigenvalues & 5.49 & 1.65 & 1.29 \\
& \%o of variance & 36.62 & 10.97 & 8.87 \\
& Cumulative \% & - & 47.59 & 56.15 \\
& Standardized Cronbach's $a$ & 0.83 & 0.77 & 0.71 \\
\hline
\end{tabular}

Note: Three items on "increase family affinity" (M5), "make new friends" (M13), and "expand social interaction" (M14) were removed due to low loading or cross loading on two factors. $\mathrm{KMO}=0.85, p<0.001$. 
Table 2. Summary results of exploratory factor analysis for motivation (Zhangiiajie, $n=560$ ).

\begin{tabular}{ccccc}
\hline \multirow{2}{*}{ Code } & Factor (Proportion): & \multicolumn{3}{c}{ Factor } \\
\cline { 3 - 5 } Scale Name \& Items & $\mathbf{1}$ & $\mathbf{2}$ & $\mathbf{3}$ \\
\hline Factor 6 & Nature affinity and relaxation (Z_MO1) & & \\
M1 & Close to nature & 0.817 & 0.139 & 0.052 \\
M2 & Nature observation & 0.830 & 0.190 & 0.072 \\
M4 & Adjust life & 0.792 & 0.171 & 0.203 \\
M10 & Be away from daily lives & 0.644 & 0.235 & 0.217 \\
M11 & Rest and relaxation & 0.774 & 0.163 & 0.205 \\
\hline Factor 2 & Authentic experience (Z_MO2) & & & \\
M7 & Experience new things & 0.255 & 0.663 & 0.200 \\
M8 & Experience local customs and culture & 0.330 & 0.787 & 0.067 \\
M9 & Understand the park's history & 0.182 & 0.834 & 0.112 \\
\hline Factor 1 & Fitness and wellbeing (Z_MO3) & & & \\
M3 & Fitness & 0.320 & 0.121 & 0.767 \\
M6 & Seek adventurous experience & 0.082 & 0.188 & 0.794 \\
M12 & Mental and physical health & 0.318 & 0.331 & 0.573 \\
\hline & Eigenvalues & 5.86 & 1.83 & 1.06 \\
& \%of variance & 41.87 & 13.04 & 7.54 \\
& Cumulative \% & - & 54.91 & 62.45 \\
\hline
\end{tabular}

Note: Three items on "increase family affinity" (M5), "make new friends" (M13), and "expand social interaction" (M14) were removed due to low loading or cross loading on two factors. $\mathrm{KMO}=0.87, p<0.001$.

Table 3. Summary results of exploratory factor analysis for attribute satisfaction (Lushan, $n=515$ ).

\begin{tabular}{ccccc}
\hline & Factor (Proportion): & \multicolumn{3}{c}{ Factor } \\
\cline { 3 - 4 } Code & Scale Name \& Items & $\mathbf{1}$ & $\mathbf{2}$ & $\mathbf{3}$ \\
\hline Factor 1 & Park management (L_SA3) & & \\
S7 & Visual quality & 0.682 & 0.282 & 0.217 \\
S8 & Overall atmosphere & 0.622 & -0.158 & 0.496 \\
S9 & Signages & 0.642 & 0.286 & 0.285 \\
S11 & Safety and security & 0.768 & 0.208 & 0.091 \\
S12 & Shopping & 0.586 & 0.565 & 0.056 \\
S13 & Food quality and sanitation & 0.704 & 0.382 & 0.060 \\
S14 & Tourism order & 0.736 & 0.139 & 0.114 \\
\hline Factor 2 & Service quality (L_SA2) & & & \\
S3 & Wildlife & 0.095 & 0.795 & 0.260 \\
S5 & Service quality & 0.392 & 0.643 & 0.176 \\
S6 & Entrance fee & 0.317 & 0.718 & 0.149 \\
\hline Factor 3 & Tourism resources (L_SA1) & & & \\
S1 & Cultural resources & 0.217 & 0.130 & 0.773 \\
S2 & Forest environment & 0.141 & 0.178 & 0.816 \\
S4 & Natural scenery & 0.083 & 0.372 & 0.603 \\
\hline & Eigenvalues & 6.23 & 1.34 & 1.14 \\
& \%of variance & 44.50 & 9.60 & 8.17 \\
& Cumulative \% & - & 54.09 & 62.25 \\
& Standardized Cronbach's $a$ & 0.87 & 0.77 & 0.71
\end{tabular}

Note: One item on the number of recreational sites was removed due to cross loading on two factors. $\mathrm{KMO}=0.85$, $p<0.001$. 
Table 4. Summary results of exploratory factor analysis for attribute satisfaction (Zhangiiajie, $n=560$ ).

\begin{tabular}{cccc}
\hline \multirow{2}{*}{ Code } & Factor (Proportion): & \multicolumn{2}{c}{ Factor } \\
& Scale Name \& Items & $\mathbf{1}$ & $\mathbf{2}$ \\
\cline { 2 - 4 } Factor 1 & Service quality \& Park management (Z_SA2) & & \\
S5 & Service quality & 0.640 & 0.321 \\
S9 & Signages & 0.586 & 0.274 \\
S10 & Number of recreation sites & 0.615 & 0.282 \\
S11 & Safety and security & 0.659 & 0.292 \\
S12 & Shopping & 0.803 & 0.116 \\
S13 & Food quality and sanitation & 0.784 & 0.124 \\
S14 & Tourism order & 0.768 & 0.202 \\
\hline Factor & Tourism resources (Z_SA1) & & \\
S1 & Cultural resources & 0.306 & 0.597 \\
S2 & Forest environment & 0.164 & 0.855 \\
S3 & Wildlife & 0.278 & 0.620 \\
S4 & Natural scenery & 0.139 & 0.808 \\
\hline & Eigenvalues & 6.20 & 1.34 \\
& \%of variance & 44.31 & 9.54 \\
& Cumulative \% & - & 53.85 \\
& Standardized Cronbach's $a$ & 0.86 & 0.77
\end{tabular}

Note: Three items on entrance fee, visual quality, and overall atmosphere were removed due to cross loading on two factors. $\mathrm{KMO}=0.91, p<0.001$.

\subsection{CFA for Measurement Model}

Tables 5 and 6 present CR, AVE, and MSV for both CFAs. The CR for each factor is above 0.70 , ranging from 0.72 to 0.86 for Lushan and 0.75 to 0.88 for Zhangjiajie. AVE is close to or above 0.50 for all factors. An AVE close to 0.50 is still adequate if CR is higher than $0.70[83,90]$. Finally, AVE is greater than MSV for all factors for both samples, except for service quality and park management for the Lushan sample whose AVE is less than one MSV. This suggests the model for both samples, particularly Zhangjiajie, has a good composite reliability, and acceptable convergent validity and discriminant validity.

Table 5. Composite reliability, average variance extracted, and maximum shared variance (Lushan, $n=515)$.

\begin{tabular}{cccc}
\hline & $\begin{array}{c}\text { Composite } \\
\text { Reliability }\end{array}$ & $\begin{array}{c}\text { Average Variance } \\
\text { Extracted }\end{array}$ & $\begin{array}{c}\text { Maximum Shared } \\
\text { Variance }\end{array}$ \\
\hline Motivation & & & \\
Fitness and relaxation & 0.83 & 0.49 & $0.08-0.39$ \\
Authentic experience & 0.78 & 0.47 & $0.09-0.39$ \\
Nature affinity & 0.72 & 0.57 & $0.00-0.18$ \\
\hline Attribute satisfaction & & & \\
Tourism resources & 0.73 & 0.49 & $0.05-0.39$ \\
Service quality & 0.76 & 0.51 & $0.00-0.64$ \\
Park management & 0.87 & 0.49 & $0.01-0.64$ \\
\hline Loyalty & 0.86 & 0.68 & $0.00-0.43$ \\
\hline
\end{tabular}


Table 6. Composite reliability, average variance extracted, and maximum shared variance (Zhangjiajie, $n=560)$.

\begin{tabular}{cccc}
\hline & $\begin{array}{c}\text { Composite } \\
\text { Reliability }\end{array}$ & $\begin{array}{c}\text { Average Variance } \\
\text { Extracted }\end{array}$ & $\begin{array}{c}\text { Maximum } \\
\text { Shared Variance }\end{array}$ \\
\hline $\begin{array}{c}\text { Motivation } \\
\text { Nature affinity and relaxation }\end{array}$ & 0.87 & & \\
Authentic experience & 0.82 & 0.58 & $0.12-0.35$ \\
Fitness and wellbeing & 0.75 & 0.50 & $0.11-0.36$ \\
Attribute satisfaction & & & $0.00-0.18$ \\
Tourism resources & 0.80 & 0.49 & $0.15-0.40$ \\
Service quality \& park management & 0.87 & 0.48 & $0.12-0.40$ \\
Loyalty & 0.88 & 0.72 & $0.09-0.40$ \\
\hline
\end{tabular}

\subsection{Structural Model}

\subsubsection{Second-Order Model}

Based on the EFA findings, there are several underlying factors for motivation and AS for both samples. The existence of subscales in motivation and AS warrants the inclusion of a second-order factor in SEM (Figure 3 for Lushan and Figure 4 for Zhangjiajie). The $\chi^{2} / d f$ values are 3.87 for Lushan and 3.62 for Zhangjiajie, which are less than 5 , indicating the data fit the model well. Other fit indices also reveal a fair model fit (RMSEA $=0.075$; $\mathrm{IFI}=0.82 ; \mathrm{CFI}=0.82$ for Lushan and RMSEA $=0.068$; IFI $=0.87 ; \mathrm{CFI}=0.87$ for Zhangjiajie) While model fit indices can be improved by removing items with lower loadings, no items were removed in this study, as $\chi^{2} / d f$ values are less than 5 and RMSEA is less than 0.08, allowing a consistent comparison across models.

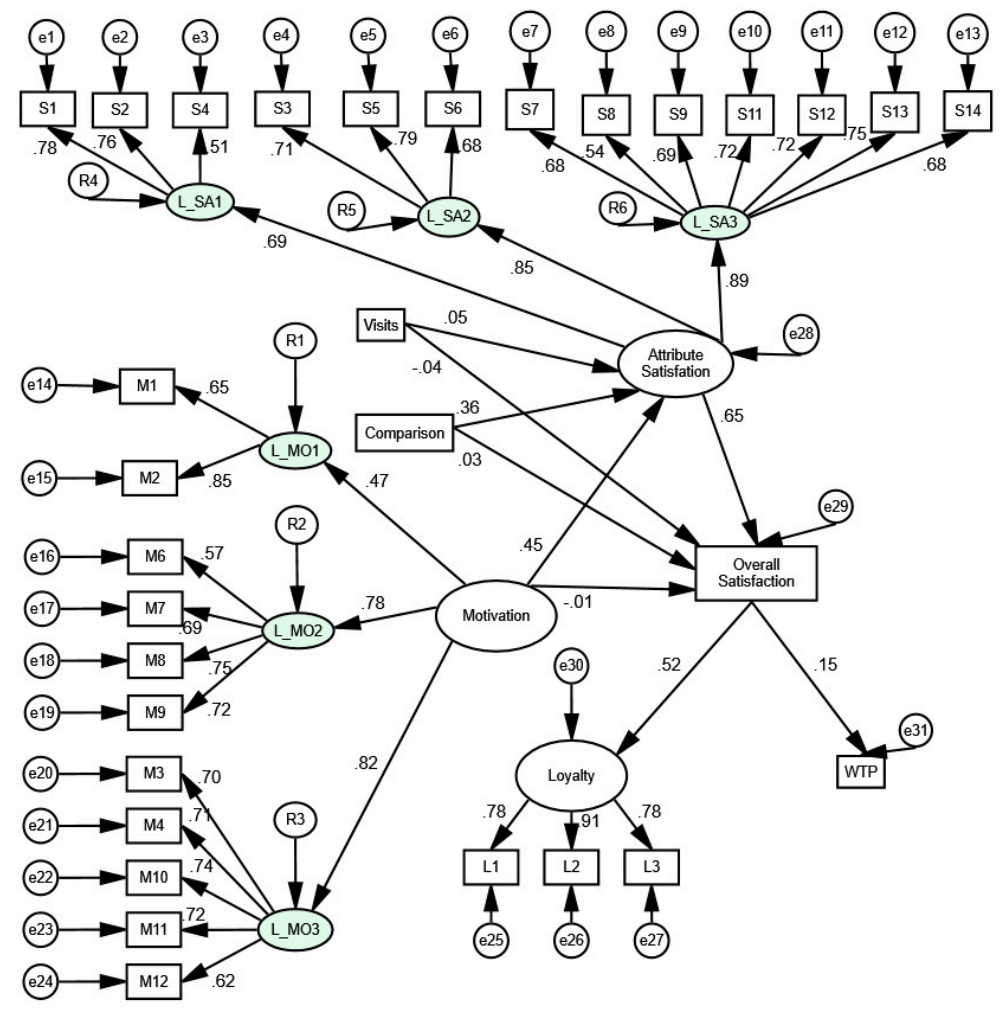

Figure 3. Second-order factor SEM for the Lushan sample. 


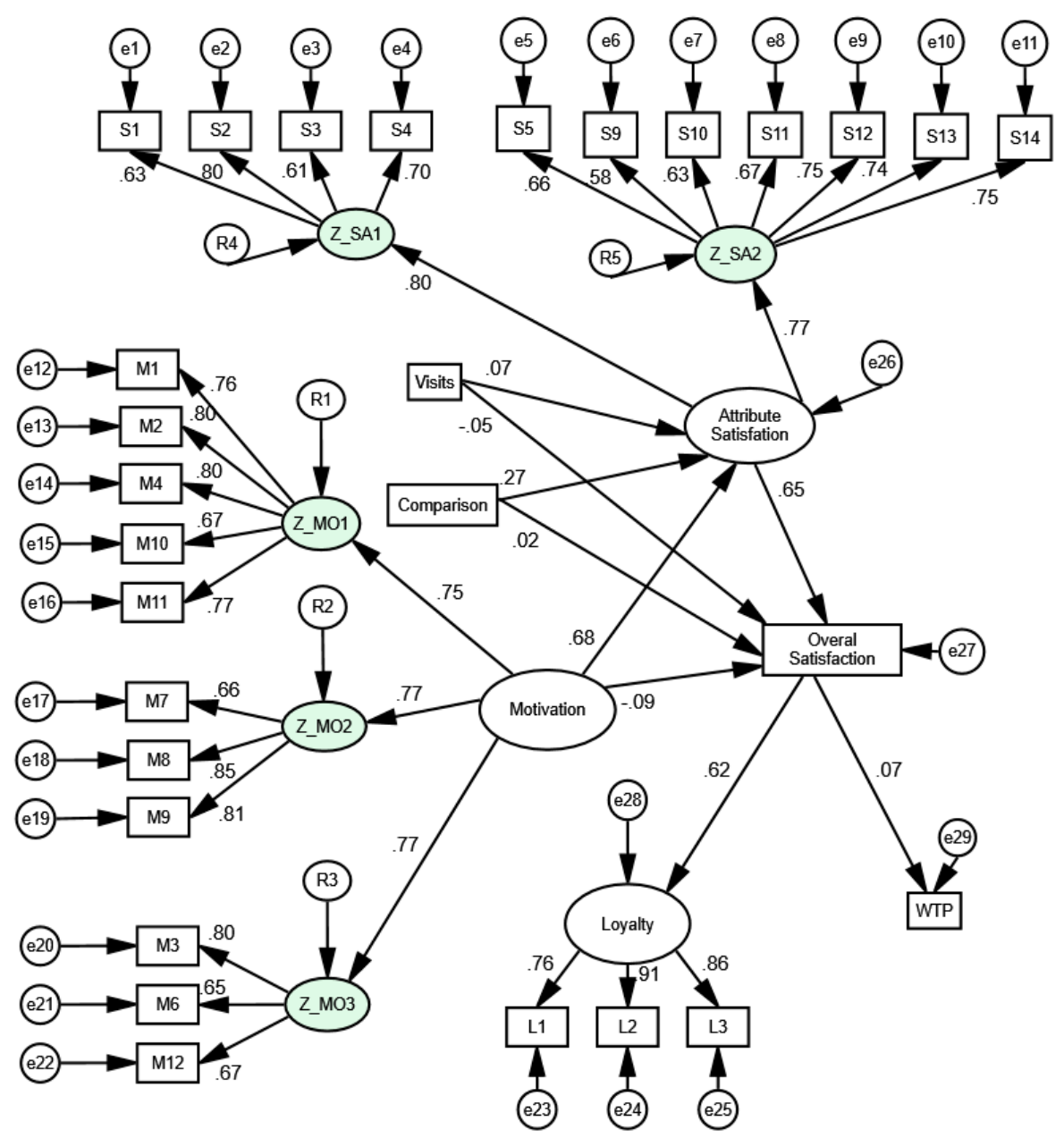

Figure 4. Second-order factor SEM for the Zhangjiajie sample.

Interestingly, findings are similar for both samples. Specifically, motivation significantly influenced AS $(p<0.001)$. However, its impact on OS was not significant $(p>0.05)$. While the impact of past experience in terms of frequency of visits on AS was not significant, nor its impact on OS, past experience with other destinations had a significant impact on AS $(p<0.001)$, although its impact on OS was not significant either. It should be noted that AS significantly predicted OS $(p<0.001)$, thus, it mediated the impact of past experience with other destinations on OS as well as the impact of motivation on OS. Finally, OS significantly predicted loyalty $(p<0.001)$. However, its impacts on WTP were not significant $(p>0.05)$ for the Zhangjiajie sample, but significant for the Lushan sample $(p<0.001)$. Table 7 presents results for hypothesis tests for both samples.

Table 7. Standardized path coefficients for structural equation model.

\begin{tabular}{|c|c|c|c|c|c|}
\hline \multirow{2}{*}{ Hypotheses } & \multirow{2}{*}{ Path } & \multicolumn{2}{|c|}{ Standardized Coefficients } & \multicolumn{2}{|c|}{ Hypothesis Supported or Not } \\
\hline & & Lushan & Zhangjiajie & Lushan & Zhangjiajie \\
\hline $\mathrm{H} 1$ & Motivation $\rightarrow$ AS & $0.45 *$ & $0.68 *$ & Yes & Yes \\
\hline $\mathrm{H} 2$ & Motivation $\rightarrow$ OS & -0.1 & -0.09 & Yes & Yes \\
\hline $\mathrm{H} 3$ & Frequency of visits $\rightarrow$ AS & 0.05 & 0.07 & No & No \\
\hline $\mathrm{H} 4$ & Frequency of visits $\rightarrow$ OS & -0.04 & -0.05 & No & No \\
\hline H5 & Destination comparison $\rightarrow$ AS & $0.36^{*}$ & $0.27 *$ & Yes & Yes \\
\hline H6 & Destination comparison $\rightarrow$ OS & 0.03 & 0.02 & No & No \\
\hline $\mathrm{H} 7$ & $\mathrm{AS} \rightarrow \mathrm{OS}$ & $0.65 *$ & $0.65 *$ & Yes & Yes \\
\hline $\mathrm{H} 8$ & OS $\rightarrow$ Loyalty & $0.52 *$ & $0.62 *$ & Yes & Yes \\
\hline H9 & $\mathrm{OS} \rightarrow \mathrm{WTP}$ & $0.15^{*}$ & 0.07 & Yes & No \\
\hline
\end{tabular}




\subsubsection{First-Order Factor Models}

As aforementioned, a first-order factor model was also examined for each sample, which is presented in Figure 5 for Lushan and Figure 6 for Zhangjiajie, respectively. Table 8 presents model fit indices for the second-order factor model and first-order factor model for each sample. While the fit indices such as IFI and CFI were comparable across models, the second-order factor model outperformed the first-order model in terms of $\chi^{2} / d f$ and RMSEA for each sample.

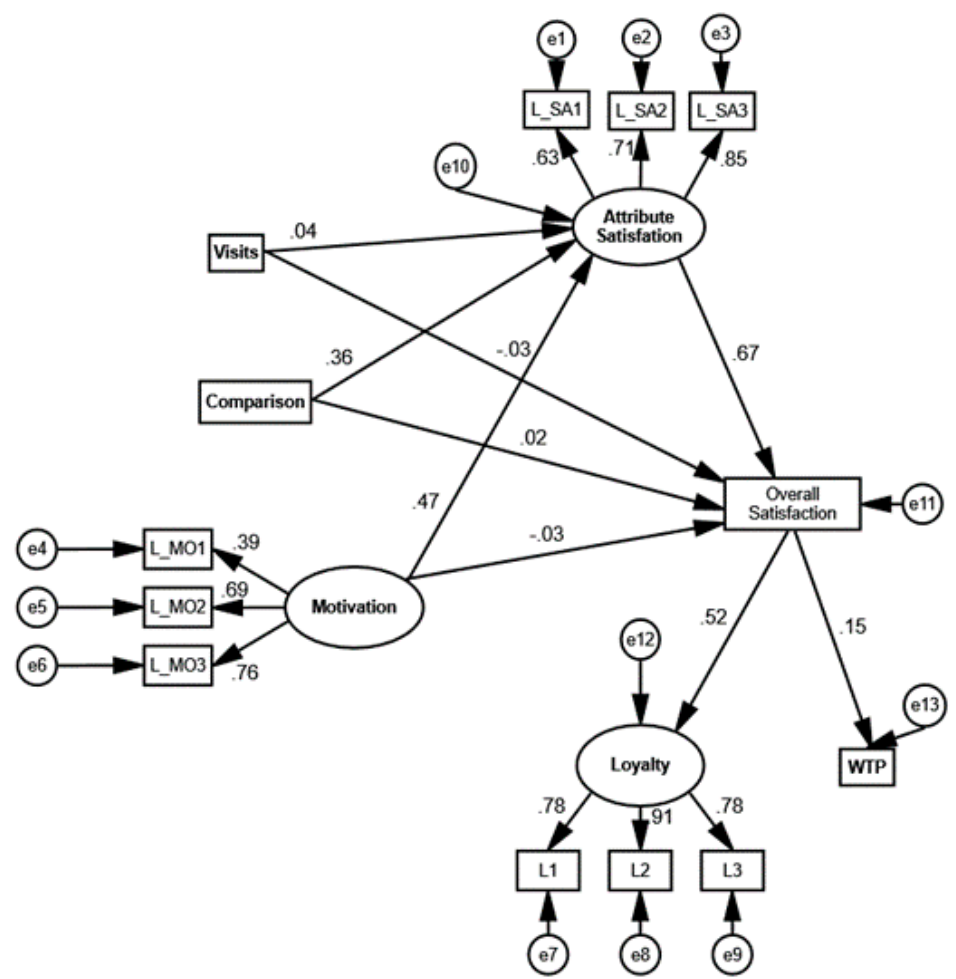

Figure 5. First-order SEM with factor means for Lushan.

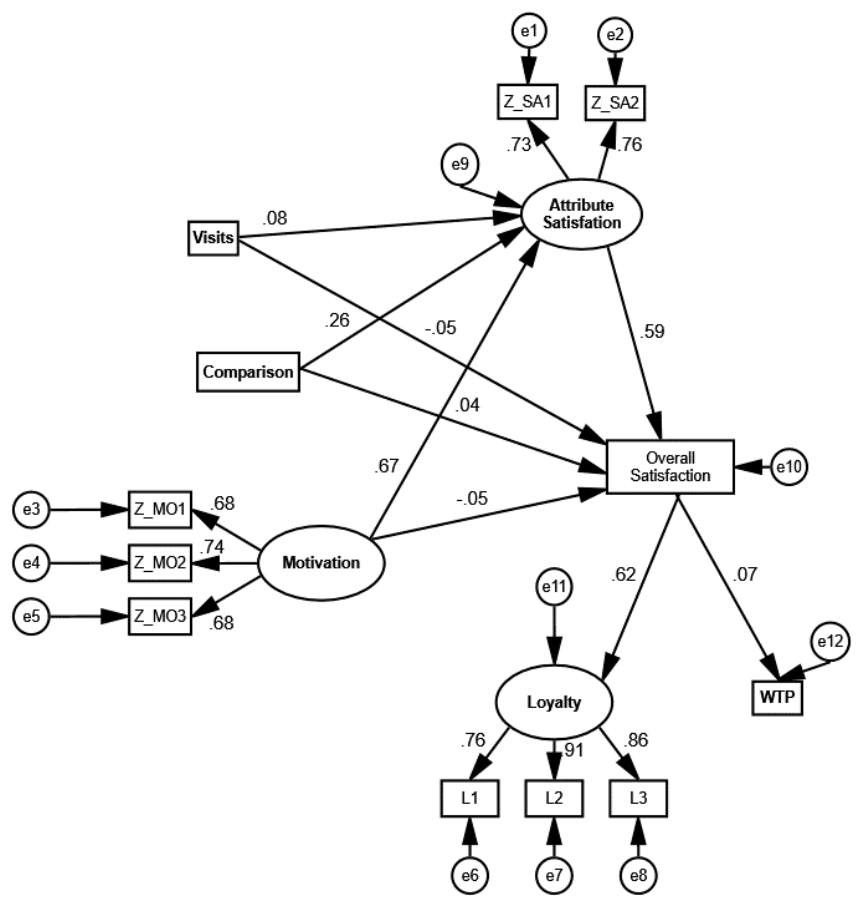

Figure 6. First-order SEM with factor means for Zhangjiajie. 
Table 8. Comparison of assessment indices.

\begin{tabular}{ccccccc}
\hline Model Fit Indices & $\chi^{2}$ & $d f$ & $\chi^{2} / d f$ & RMSEA & IFI & CFI \\
\hline \multirow{2}{*}{ Second-order model } & 1639.42 & 424 & 3.87 & 0.075 & 0.82 & 0.82 \\
& $(1326.92)$ & $(367)$ & $(3.62)$ & $(0.068)$ & $(0.87)$ & $(0.87)$ \\
\hline \multirow{2}{*}{ First-order model } & 412.12 & 60 & 6.87 & 0.11 & 0.85 & 0.85 \\
& $(233.80)$ & $(49)$ & $(4.77)$ & $(0.082)$ & $(0.92)$ & $(0.92)$ \\
\hline
\end{tabular}

Note: values in parentheses refer to the Zhangjiajie sample.

It is worth nothing that, although the model fit indices vary across models, the relationship magnitudes between any two given variables and associated significant levels were similar from model to model. This consistency cross-validated the findings that it is the past experience with other destinations, not the frequency of visits to the same destination, that directly influenced AS and indirectly influenced OS via AS.

\section{Discussion and Conclusions}

To test the destination loyalty model involving visitors' past experience (with the same destination as well as with other similar destinations) and their behavioral intentions (revisit/word of mouth and WTP), a second-order SEM was built and tested using data collected from face-to-face onsite surveys of visitors in two national parks in China. Three other variables-motivation, AS, and OS-were also included in the model. Results are highly comparable between the two samples. Previous experience with other destination(s) significantly and positively influenced AS $(p<0.001)$. That is, visitors who felt their current experience with the park was better than their previous experience with other destination(s) were more likely to feel satisfied at the attribute level. This finding endorses a previous study [8]. However, its impact on OS was not significant (although the relationship was positive). Since AS significantly and positively influenced OS $[3,16,49,61]$, it mediated the impact of previous experience with other destination(s) on OS.

Interestingly, frequency of visits had no significant impacts on AS nor on OS. This finding was consistent with some studies $[27,28]$, but not aligned with most others where repeaters were found to be more satisfied or loyal than first timers $[3,4,6,7,11,18-22]$. This finding may suggest that both first timers and repeaters were equally satisfied with their vitiation in the parks, and thus the Law of Diminishing Marginal Utility did not apply to each park, which is primarily dominated by nature-based attractions that are geologically unique not only in China, but also globally. Previous studies have found that first timers and repeaters were affected differently under different circumstances when their satisfactions were comparatively examined [30-33], whereas uniqueness was not considered. Thus, uniqueness of attractions may play a different role from other factors in affecting satisfaction for the two groups.

As with past experience with other destination(s), motivation had a significant and positive impact on AS, which mediated its impact on OS, although its direct impact on OS was not significant. This finding was consistent with some studies [47] where motivation did not contribute directly to OS. It also corroborated one study [91] that the two variables were indirectly related.

While OS's impact on revisit intention/word of mouth was found to be significant and positive $(p<0.001)$, which endorsed the general literature as well as a specific study related to Zhangjiajie park [92-95], its impact on WTP was not significant, which is different than findings reported in other studies $[11,13,14,53,54]$. This suggests that visitors may be prone to saying positive things about a destination while being a little conservative when asked to pay. Thus, asymmetric beliefs in a destination loyalty may exist, depending on how behavior intention was measured. That said, the impact of WTP on loyalty was positive for Lushan, implying the entrance fee played a role in affecting visitors' loyalty. It is worth noting that the entrance fee of $¥ 248 \mathrm{RMB}$ (approximately \$38.3) for Zhangjiajie is much higher than the entrance fee of $¥ 180$ RMB (approximately \$27.8) for Lushan, resulting in a 
lower WTP for Zhangiiajie (¥111 RMB, approximately \$17.1) than for Lushan (¥130 RMB, approximately $\$ 20.1$. This indicates that the entrance fee for the former was less reasonable than the latter.

\subsection{Research Limits and Future Research Needs}

Although this study is among the first that simultaneously examines the two types of past experience, motivation, and WTP using a second-order SEM, it is not without limitations. First, the nature of the impact of motivation on AS and OS may depend on the timing of its measurement. That is, motivation measured before the experience, onsite, and after the experience may affect AS or OS differently [47]. Thus, future research needs to measure motivation at different occasions to fully understand the impact of motivation on AS or OS. Second, this study asked participants to compare each park with similar destination(s) visited without asking them to specify which destination(s) were visited. Future research may need to ask participants to name those similar destinations so that the park can better understand its competitive market(s). In addition, the study did not ask participants anything regarding their previous visits abroad, which may affect their evaluation of the two parks visited. For example, people who visited Yellowstone National Park in the USA and/or Banff National Park in Canada may perceive the two parks differently from those who did not. Thus, it would be interesting to compare these two groups in future research. Finally, not all people are interested in visiting natural settings such as national parks, some may feel more comfortable in a built environment and may prefer to recreate in urban areas. Moreover, people's perceptions of national parks/wilderness may change over time and there is no guarantee that our future generations will value national parks/wilderness in the same way that we value today. Consequently, it is necessary to monitor the dynamic of people's preferences for tourism destinations, including national parks. Given most satisfaction and loyalty studies are focused on hospitability and resorts, more studies are needed to examine people's satisfaction and loyalty related to national parks.

\subsection{Research Implications}

Despite the limitations noted above, this study is of significant theoretical, methodological, and managerial implications. Theoretically, while expectation-confirmation theory [96] has been widely applied to the field of tourism studies, its applications are largely limited to the same destinations, with few studies focused on experience comparisons of different destinations. Previous studies in other disciplines have applied Social Comparison Theory [94] to assess one's self-reported happiness, finding that how happy or satisfied an individual is depends on how they compare with others. For example, one study [95] used the data from the World Values Survey to examine the relationships between selfreported happiness and the levels of income, finding that "changes in relative income have much larger effects on happiness than do changes in absolute income" (p. 497). Similar findings are also reported by others in the context of China [96-98]. Given the limitation of the expectation-confirmation theory to different destinations/services/products, some scholars [99] proposed an alternative model "with experience-based norms as the consumer's standard of comparison" [100] (p. 19). Findings from this study endorse the "experience-based norms" model, and thus contribute to the development of theories on relative/comparative satisfaction as it applies to tourism destinations. It is argued [62] that the expectancy-disconfirmation theory "does not seem to provide comparative information on performance of competitors, which is necessary for managers in planning competitive actions" (p. 110), which was empirically supported by this study. It is worth noting that this study found that it is the comparison with other destinations that affected visitors attribute satisfaction, which, in turn, affected overall satisfaction. A further look at the relationship between OS and the differences between attribute satisfaction and attribute expectation (Appendix C) shows the expectancy-disconfirmation theory did not apply to this study (the Zhangjiajie sample). As shown by the iso-rating line in Figure A1, all attribute satisfactions are below attribute expectations, except for point 2 (forest envi- 
ronment), which is positioned on the 45-degree diagonal line. This suggests, based on the expectancy-disconfirmation theory, that only forest environment would contribute to OS because its performance met its expectation, while all other items would negatively affect OS because their performances fell short of expectations. However, a linear regression analysis of OS against all 14 expectancy-disconfirmation measures (Table A9) shows that while forest environment significantly and positively predicts OS, conforming the expectancy-disconfirmation theory, none of the remaining 13 expectancy-disconfirmation variables are significant $(p>0.05)$, indicating the discrepancy between attribute satisfaction and attribute expectation did not affect OS, which is different than what is implied by the expectancy-disconfirmation theory.

Methodologically, the second order SEM is found to be the best in terms of model fit. A second-order SEM "recognizes the contribution and retains the idiosyncratic nature of each first-order construct" [101]. In addition, this study also endorses the use of factor means in an SEM in previous studies $[8,16,17]$. Finally, the magnitude and sign of the relationship between OS and WTP can be used to understand visitors' perceptions of the entrance fees being acceptable or not for a destination.

Managerially, the insignificant relationship between OS and WTP for the Zhangjiajie sample indicates that the park's entrance fee of $¥ 248$ (approximately $\$ 38.3$ ) is much higher than expected, resulting in visitors being less willing to pay more even with a higher level of satisfaction. It should be noted that most of China's tourism destinations depend on entrance fees as their major source of economic revenues. This so-called "ticket economy" in the country has been criticized among scholars for many years as it deters tourists from spending more on other services/products in a destination, thus contributing less to gateway communities. A study by China Tourism Academy shows that over $90 \%$ of survey participants thought the entrance fee for a 5A tourism area should be within $¥ 100$ (approximately \$15.4) [102], which is close to the average WTP of $¥ 111$ (approximately \$17.1) for the park reported by tourists in this study, which is also a 5A destination in the country. It should be noted that some countries do not charge entrance fees or charge at a low cost. For example, entrance to the most visited Great Smoky Mountains National Park in the USA is free, while the annual pass of $\$ 80$ allows unlimited access to all national parks that charge entrance fees. It is the authors' hope that this annual pass module would be followed in China in the near future.

Author Contributions: Conceptualization, J.Y.; revision, graphics, and project administration, J.L.; methodology, J.D.; formal analysis, J.D.; investigation, J.Y.; writing-original draft preparation, J.D.; writing-review and editing, D.A.; funding acquisition, J.Y. All authors have read and agreed to the published version of the manuscript.

Funding: This research was funded by the State Administration of Forestry and Grassland, China, grant number 2018-R22.

Institutional Review Board Statement: Ethical review and approval were waived for this study, due to the study being approved by the two national park administrations.

Informed Consent Statement: Not applicable.

Data Availability Statement: Data supporting reported results can be found at Harvard Dataverse, https:/ / doi.org/10.7910/DVN/FSWXN1 (accessed on 20 July 2021).

Acknowledgments: Thanks go to the faculty and students from the College of Tourism, Central South University of Forestry \& Technology for their help with data collection. Thanks also go to Chad Pierskalla for his review of an earlier version of this manuscript.

Conflicts of Interest: The authors declare no conflict of interest. 


\section{Appendix A. Survey Questionnaire}

\section{Survey of Visitors' Satisfaction}

This survey questionnaire consists of seven sections, including trip/socio-demographic characteristics, motivation, attribute importance, expectation, satisfaction, behavioral intention, and willingness to pay. Please answer the following questions by circling the number next to the most appropriate answer or by writing your answer in the space provided. All information collected will be kept confidential. If for any reason you do not want to answer a particular question, please skip it. The purpose of Tthis survey is solely for the purpose of academic research. It maywill take you about $5 \mathrm{~min}$ to complete the questionnaire. Thank you very much!

\section{Section I: Trip/Socio-demographic Characteristics}

1. Sex: $\square$ male $\square$ female

2. Age:

$\square 16-17 \square 18-24 \square 25-34 \square 35-44 \square 45-65 \square 65+$

\section{Education:}

$\square$ Junior High $\square$ High School $\square$ Undergraduate $\square$ Graduate

4. Individual annual income before tax in the previous year:

$\square$ Less than 12,000 RMB $\square 12,000-30,000$ RMB $\square 30,001-60,000$ RMB

$\square 60,001-80,000$ RMB $\square 80,001-100,000$ RMB $\square$ More than 100,000 RMB

5. Frequency of visits:

$\square$ First time $\square 2$ times $\square 3$ times $\square 4$ times $\square$ More than 5 times

6 . To what extent do you think the park is better or worse than a similar destination (s) you visited before?

$\square$ Much worse $\square$ Worse $\square$ More or less the same $\square$ Better $\square$ Much better

Section II: Travel Motivations

Listed below are phrases about your motivations to visit the park. Please indicate how much you disagree or agree with each phrase by circling your response.

\begin{tabular}{cccccc}
\hline Items & $\begin{array}{c}\text { Strongly } \\
\text { Disagree }\end{array}$ & $\begin{array}{c}\text { Mildly } \\
\text { Disagree }\end{array}$ & Neutral & $\begin{array}{c}\text { Mildly } \\
\text { Agree }\end{array}$ & $\begin{array}{c}\text { Strongly } \\
\text { Agree }\end{array}$ \\
\hline M1. Close to nature & 1 & 2 & 3 & 4 & 5 \\
M2. Nature observation & 1 & 2 & 3 & 4 & 5 \\
M3. Fitness & 1 & 2 & 3 & 4 & 5 \\
M4. Adjust life & 1 & 2 & 3 & 4 & 5 \\
M5. Increase family affinity & 1 & 2 & 3 & 4 & 5 \\
M6. Seek adventurous experience & 1 & 2 & 3 & 4 & 5 \\
M7. Experience new things & 1 & 2 & 3 & 4 & 5 \\
\hline M8. Experience local customs and culture & 1 & 2 & 3 & 4 & 5 \\
M9. Understand the park's history & 1 & 2 & 3 & 4 & 5 \\
M10. Be away from daily lives & 1 & 2 & 3 & 4 & 5 \\
M11. Rest and relax & 1 & 2 & 3 & 4 & 5 \\
M12. Mental and physical health & 1 & 2 & 3 & 4 & 5 \\
M13. Make new friends & 1 & 2 & 3 & 4 & 5 \\
M14. Expand social interaction & 1 & 2 & 3 & 4 & 5 \\
\hline
\end{tabular}


Section III Attribute Importance (for Lushan only)

Listed below are tourism attributes in Lushan. Please indicate how much you disagree or agree with each phrase by circling your response.

\begin{tabular}{cccccc}
\hline Items & $\begin{array}{c}\text { Strongly } \\
\text { Disagree }\end{array}$ & $\begin{array}{c}\text { Mildly } \\
\text { Disagree }\end{array}$ & $\begin{array}{c}\text { Neutral } \\
\text { I1. Cultural resources }\end{array} \quad 1 \quad \begin{array}{c}\text { Mildly } \\
\text { Agree }\end{array}$ & $\begin{array}{c}\text { Strongly } \\
\text { Agree }\end{array}$ \\
\hline I2. Forest environment & 1 & 2 & 3 & 4 & 5 \\
I3. Wildlife & 1 & 2 & 3 & 4 & 5 \\
I4. Natural scenery & 1 & 2 & 3 & 4 & 5 \\
I5. Service quality & 1 & 2 & 3 & 4 & 5 \\
I6. Entrance fee & 1 & 2 & 3 & 4 & 5 \\
I7. Visual quality & 1 & 2 & 3 & 4 & 5 \\
I8. Overall atmosphere & 1 & 2 & 3 & 4 & 5 \\
I9. Signages & 1 & 2 & 3 & 4 & 5 \\
I10. Number of recreational sites & 1 & 2 & 3 & 4 & 5 \\
I11. Safety and security & 1 & 2 & 3 & 4 & 5 \\
I12. Shopping & 1 & 2 & 3 & 4 & 5 \\
I13. Food quality and sanitation & 1 & 2 & 3 & 4 & 5 \\
I14. Tourism order & 1 & 2 & 3 & 4 & 5 \\
\hline
\end{tabular}

Section IV Attribute Expectation (for Zhangjiajie only)

Listed below are attributes that you may expect to experience in Zhangjiajie. Please indicate how much you disagree or agree with each expectation by circling your response.

\begin{tabular}{cccccc}
\hline Items & $\begin{array}{c}\text { Strongly } \\
\text { Disagree }\end{array}$ & $\begin{array}{c}\text { Mildly } \\
\text { Disagree }\end{array}$ & Neutral & $\begin{array}{c}\text { Mildly } \\
\text { Agree }\end{array}$ & $\begin{array}{c}\text { Strongly } \\
\text { Agree }\end{array}$ \\
\hline I1. Cultural resources & 1 & 2 & 3 & 4 & 5 \\
I2. Forest environment & 1 & 2 & 3 & 4 & 5 \\
I3. Wildlife & 1 & 2 & 3 & 4 & 5 \\
I4. Natural scenery & 1 & 2 & 3 & 4 & 5 \\
I5. Service quality & 1 & 2 & 3 & 4 & 5 \\
I6. Entrance fee & 1 & 2 & 3 & 4 & 5 \\
I7. Visual quality & 1 & 2 & 3 & 4 & 5 \\
I8. Overall atmosphere & 1 & 2 & 3 & 4 & 5 \\
I9. Signages & 1 & 2 & 3 & 4 & 5 \\
I10. Number of recreational sites & 1 & 2 & 3 & 4 & 5 \\
I11. Safety and security & 1 & 2 & 3 & 4 & 5 \\
I12. Shopping & 1 & 2 & 3 & 4 & 5 \\
I13. Food quality and sanitation & 1 & 2 & 3 & 4 & 5 \\
I14. Tourism order & 1 & 2 & 3 & 4 & 5 \\
\hline
\end{tabular}

Section V. Destination Satisfaction

Please indicate how dissatisfied or satisfied you are with each of the following activities/services? 


\begin{tabular}{cccccc}
\hline Items & $\begin{array}{c}\text { Very } \\
\text { Dissatisfied }\end{array}$ & $\begin{array}{c}\text { Somewhat } \\
\text { Dissatisfied }\end{array}$ & Neutral & $\begin{array}{c}\text { Somewhat } \\
\text { Satisfied }\end{array}$ & $\begin{array}{c}\text { Very } \\
\text { Satisfied }\end{array}$ \\
\hline S1. Cultural resources & 1 & 2 & 3 & 4 & 5 \\
S2. Forest environment & 1 & 2 & 3 & 4 & 5 \\
S3. Wildlife & 1 & 2 & 3 & 4 & 5 \\
S4. Natural scenery & 1 & 2 & 3 & 4 & 5 \\
S5. Service quality & 1 & 2 & 3 & 4 & 5 \\
S6. Entrance fee & 1 & 2 & 3 & 4 & 5 \\
S7. Visual quality & 1 & 2 & 3 & 4 & 5 \\
S8. Overall atmosphere & 1 & 2 & 3 & 4 & 5 \\
S9. Signages & 1 & 2 & 3 & 4 & 5 \\
S10. Number of & 1 & 2 & 3 & 4 & 5 \\
recreational sites & 1 & 2 & 3 & 4 & 5 \\
S11. Safety and security & 1 & 2 & 3 & 4 & 5 \\
S12. Shopping & 1 & 2 & 3 & 4 & 5 \\
S13. Food quality and & 1 & 2 & 3 & 4 & 5 \\
sanitation & 1 & 2 & 3 & 4 & 5 \\
S14. Tourism order & 1 & & & & 5 \\
OS. Overall satisfaction & 1 & & & & 4 \\
\hline
\end{tabular}

Section VI. Destination Loyalty (Behavioral Intention)

Please indicate how likely you will revisit or recommend the park to others.

\begin{tabular}{cccccc}
\hline Items & $\begin{array}{c}\text { Strongly } \\
\text { Disagree }\end{array}$ & $\begin{array}{c}\text { Mildly } \\
\text { Disagree }\end{array}$ & Neutral & $\begin{array}{c}\text { Mildly } \\
\text { Agree }\end{array}$ & $\begin{array}{c}\text { Strongly } \\
\text { Agree }\end{array}$ \\
\hline $\begin{array}{c}\text { L1. Will visit again } \\
\text { L2. Will recommend to } \\
\text { family/others }\end{array}$ & 1 & 2 & 3 & 4 & 5 \\
L3. Will say positively about the park & 1 & 2 & 3 & 4 & 5 \\
\hline
\end{tabular}

Section VII. Willingness to Pay

If there are no entrance fees, how much would you be willing to pay to enter the park? RMB

Any comments on this study and tourism in the park?

Thank you once again for your help and cooperation!

Appendix B. Descriptive Analysis for Lushan and Zhangjiajie

Descriptive analysis for Lushan

Table A1. Descriptive analysis of overall satisfaction.

\begin{tabular}{ccccc}
\hline $\boldsymbol{N}$ & Mean & SD & Skewness & Kurtosis \\
\hline 515 & 3.61 & 0.89 & -0.508 & 0.093 \\
\hline
\end{tabular}


Table A2. Descriptive analysis of motivations (observed variables).

\begin{tabular}{lccccc}
\hline \multicolumn{1}{c}{ Item } & N & Mean & SD & Skewness & Kurtosis \\
\hline M1. Close to nature & 515 & 3.84 & 1.07 & -0.982 & 0.464 \\
M2. Nature observation & 515 & 3.58 & 1.03 & -0.636 & -0.170 \\
M3. Fitness & 515 & 4.00 & 0.97 & -0.931 & 0.577 \\
M4. Adjust life & 515 & 3.97 & 0.90 & -0.775 & 0.663 \\
M5. Increase family affinity & 515 & 3.84 & 0.97 & -0.771 & 0.369 \\
M6. Seek adventurous experience & 515 & 3.31 & 1.12 & -0.229 & -0.573 \\
M7. Experiencing new things & 515 & 3.63 & 1.01 & -0.539 & -0.028 \\
M8. Experience local customs and culture & 515 & 3.42 & 1.09 & -0.346 & -0.391 \\
M9. Understand the park's history & 515 & 3.60 & 1.00 & -0.296 & -0.340 \\
M10. Be away from daily lives & 515 & 3.62 & 1.03 & -0.513 & -0.137 \\
M11. Rest and relaxation & 515 & 3.74 & 1.03 & -0.601 & -0.027 \\
M12. Mental and physical health & 515 & 3.63 & 0.97 & -0.355 & -0.250 \\
M13. Make new friends & 515 & 3.51 & 1.00 & -0.295 & -0.226 \\
M14. Expand social interaction & 515 & 3.18 & 0.98 & -0.065 & -0.028 \\
\hline
\end{tabular}

Table A3. Descriptive analysis of satisfaction (observed variables).

\begin{tabular}{lccccc}
\hline \multicolumn{1}{c}{ Item } & N & Mean & SD & Skewness & Kurtosis \\
\hline S1. Cultural resources & 515 & 3.92 & 0.77 & -0.431 & 0.091 \\
S2. Forest environment & 515 & 4.10 & 0.76 & -0.635 & 0.400 \\
S3. Wildlife & 515 & 3.71 & 0.86 & -0.413 & -0.036 \\
S4. Natural scenery & 515 & 4.10 & 0.70 & -0.622 & 0.894 \\
S5. Service quality & 515 & 3.29 & 1.08 & -0.276 & -0.569 \\
S6. Entrance fee & 515 & 3.66 & 0.98 & -0.351 & -0.620 \\
S7. Visual quality & 515 & 3.47 & 0.93 & -0.112 & -0.347 \\
S8. Overall atmosphere & 515 & 3.78 & 0.87 & -0.390 & -0.292 \\
S9. Signages & 515 & 3.51 & 0.93 & -0.154 & -0.549 \\
S10. Number of recreational sites & 515 & 3.83 & 0.86 & -0.547 & -0.019 \\
S11. Safety and security & 515 & 3.51 & 1.02 & -0.455 & -0.242 \\
S12. Shopping & 515 & 3.52 & 0.95 & -0.204 & -0.180 \\
S13. Food quality and sanitation & 515 & 3.46 & 0.94 & -0.268 & -0.463 \\
S14. Tourism order & 515 & 3.49 & 0.92 & -0.342 & 0.016 \\
\hline
\end{tabular}

Table A4. Descriptive analysis of loyalty (observed variables).

\begin{tabular}{lccccc}
\hline \multicolumn{1}{c}{ Item } & N & Mean & SD & Skewness & Kurtosis \\
\hline L1. Will visit again & 515 & 3.64 & 0.909 & -0.545 & 0.092 \\
L2. Will recommend to family/others & 515 & 3.84 & 0.796 & -0.640 & 0.714 \\
L3. Will say positively about the area & 515 & 3.75 & 0.862 & -0.527 & -0.270 \\
\hline
\end{tabular}

\section{Descriptive analysis for Zhangjiajie}

Table A5. Descriptive analysis of overall satisfaction.

\begin{tabular}{ccccc}
\hline$N$ & Mean & $S D$ & Skewness & Kurtosis \\
\hline 560 & 3.78 & 0.79 & -0.573 & 0.638 \\
\hline
\end{tabular}


Table A6. Descriptive analysis of motivations (observed variables).

\begin{tabular}{lccccc}
\hline \multicolumn{1}{c}{ Item } & N & Mean & SD & Skewness & Kurtosis \\
\hline M1. Close to nature & 560 & 4.38 & 0.85 & -1.526 & 2.555 \\
M2. Nature observation & 560 & 4.36 & 0.83 & -1.474 & 2.638 \\
M3. Fitness & 560 & 4.00 & 1.01 & -0.943 & 0.515 \\
M4. Adjust life & 560 & 4.26 & 0.85 & -1.128 & 1.359 \\
M5. Increase family affinity & 560 & 4.00 & 1.04 & -0.841 & 0.007 \\
M6. Seek adventurous experience & 560 & 3.74 & 1.08 & -0.555 & -0.331 \\
M7. Experiencing new things & 560 & 3.91 & 0.98 & -0.632 & -0.119 \\
M8. Experience local customs and culture & 560 & 3.83 & 1.01 & -0.473 & -0.469 \\
M9. Understand the park's history & 560 & 3.74 & 1.01 & -0.380 & -0.519 \\
M10. Be away from daily lives & 560 & 4.00 & 0.99 & -0.888 & 0.367 \\
M11. Rest and relaxation & 560 & 4.28 & 0.86 & -1.290 & 1.905 \\
M12. Mental and physical health & 560 & 3.92 & 0.91 & -0.494 & -0.251 \\
M13. Make new friends & 560 & 3.44 & 1.08 & -0.173 & -0.572 \\
M14. Expand social interaction & 560 & 3.64 & 1.05 & -0.378 & -0.531 \\
\hline
\end{tabular}

Table A7. Descriptive analysis of satisfaction (observed variables).

\begin{tabular}{lccccc}
\hline \multicolumn{1}{c}{ Item } & N & Mean & SD & Skewness & Kurtosis \\
\hline S1. Cultural resources & 560 & 3.76 & 0.83 & -0.188 & -0.469 \\
S2. Forest environment & 560 & 4.23 & 0.74 & -0.766 & 0.485 \\
S3. Wildlife & 560 & 3.87 & 0.99 & -0.809 & 0.253 \\
S4. Natural scenery & 560 & 4.30 & 0.71 & -0.747 & 0.165 \\
S5. Service quality & 560 & 3.68 & 0.95 & -0.370 & -0.239 \\
S6. Entrance fee & 560 & 3.49 & 10.00 & -0.035 & -0.870 \\
S7. Visual quality & 560 & 3.79 & 0.87 & -0.205 & -0.500 \\
S8. Overall atmosphere & 560 & 4.14 & 0.77 & -0.693 & 0.308 \\
S9. Signages & 560 & 3.74 & 0.94 & -0.573 & 0.131 \\
S10. Number of recreational sites & 560 & 3.90 & 0.83 & -0.457 & -0.018 \\
S11. Safety and security & 560 & 3.85 & 0.87 & -0.487 & 0.005 \\
S12. Shopping & 560 & 3.47 & 10.03 & -0.269 & -0.459 \\
S13. Food quality and sanitation & 560 & 3.58 & 0.94 & -0.169 & -0.308 \\
S14. Tourism order & 560 & 3.72 & 0.94 & -0.373 & -0.225 \\
\hline
\end{tabular}

Table A8. Descriptive analysis of loyalty (observed variables).

\begin{tabular}{lccccc}
\hline \multicolumn{1}{c}{ Item } & N & Mean & SD & Skewness & Kurtosis \\
\hline L1. Will visit again & 560 & 3.64 & 0.909 & -0.300 & -0.542 \\
L2. Will recommend to family/others & 560 & 3.84 & 0.796 & -0.685 & 0.490 \\
L3. Will say positively about the area & 560 & 3.75 & 0.862 & -0.554 & 0.074 \\
\hline
\end{tabular}


Appendix C. Expectancy-Disconfirmation Analysis

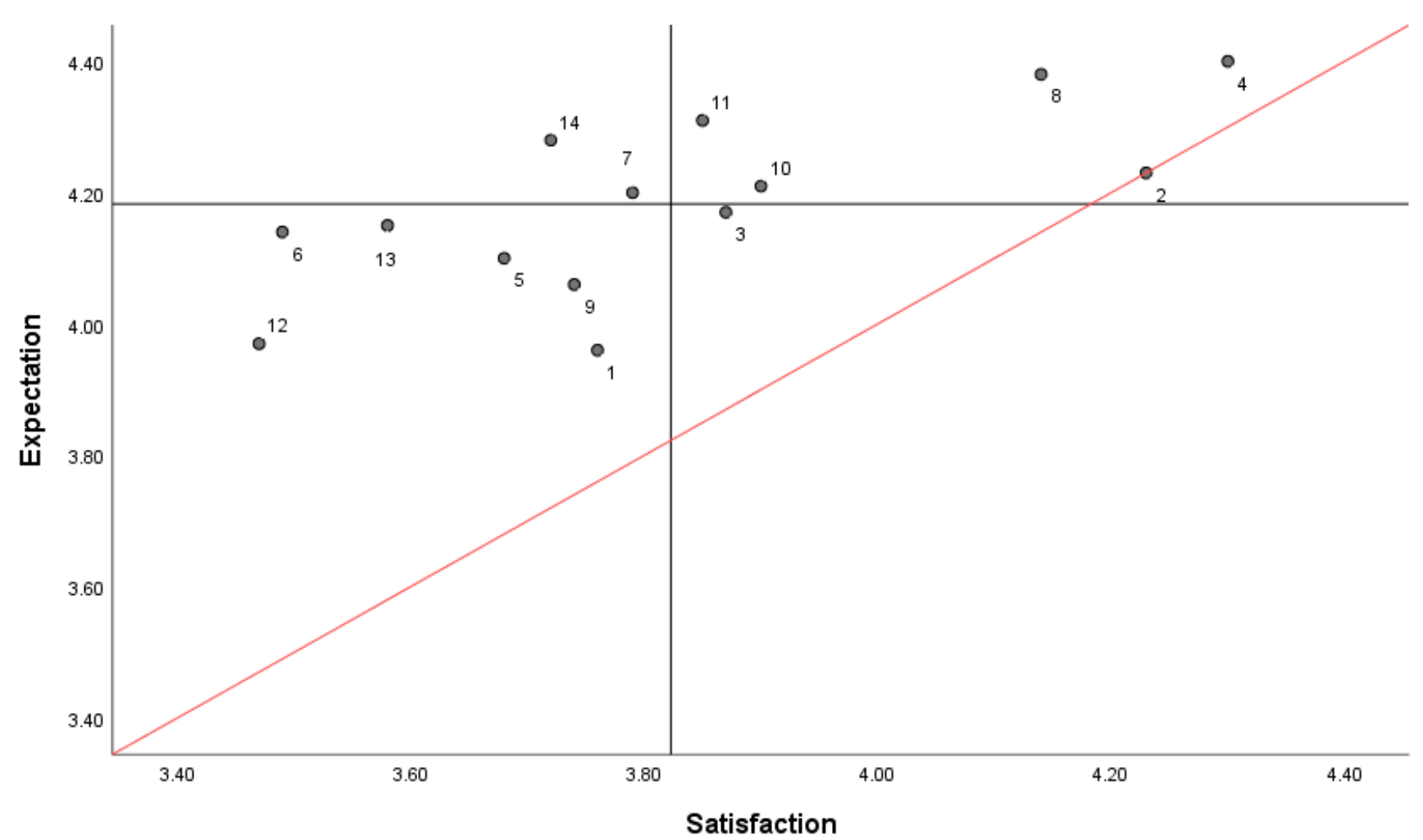

Figure A1. Expectancy-Confirmation Analysis.

Table A9. Regression analysis of overall satisfaction over the differences of between satisfaction and expectation.

\begin{tabular}{|c|c|c|c|c|c|c|c|}
\hline & \multicolumn{2}{|c|}{ Unstandardized Coefficients } & \multirow{2}{*}{$\begin{array}{c}\text { Standardized Coefficients } \\
\text { Beta }\end{array}$} & \multirow{2}{*}{$\mathbf{t}$} & \multirow{2}{*}{ Sig. } & \multicolumn{2}{|c|}{ Collinearity Statistics } \\
\hline & B & Std. Error & & & & Tolerance & VIF \\
\hline Constant & 30.857 & 0.040 & & 960.060 & 0.000 & & \\
\hline SE1 & -0.081 & 0.043 & -0.092 & -10.894 & 0.059 & 0.730 & 10.370 \\
\hline SE2 & 0.110 & 0.049 & 0.112 & 20.263 & 0.024 & 0.708 & 10.412 \\
\hline SE3 & 0.010 & 0.038 & 0.013 & 0.268 & 0.789 & 0.748 & 10.337 \\
\hline SE4 & 0.011 & 0.049 & 0.011 & 0.224 & 0.823 & 0.721 & 10.387 \\
\hline SE5 & 0.054 & 0.037 & 0.076 & 10.474 & 0.141 & 0.645 & 10.549 \\
\hline SE6 & 0.047 & 0.033 & 0.073 & 10.420 & 0.156 & 0.656 & 10.524 \\
\hline SE7 & -0.011 & 0.040 & -0.014 & -0.283 & 0.778 & 0.678 & 10.476 \\
\hline SE8 & -0.039 & 0.045 & -0.042 & -0.854 & 0.393 & 0.709 & 10.410 \\
\hline SE9 & -0.020 & 0.038 & -0.026 & -0.534 & 0.593 & 0.749 & 10.334 \\
\hline SE10 & -0.002 & 0.038 & -0.003 & -0.063 & 0.949 & 0.774 & 10.291 \\
\hline SE11 & 0.004 & 0.041 & 0.005 & 0.098 & 0.922 & 0.617 & 10.620 \\
\hline SE12 & 0.043 & 0.035 & 0.069 & 10.232 & 0.218 & 0.559 & 10.787 \\
\hline SE13 & -0.002 & 0.041 & -0.003 & -0.043 & 0.966 & 0.485 & 20.063 \\
\hline SE14 & 0.068 & 0.042 & 0.091 & 10.632 & 0.103 & 0.557 & 10.794 \\
\hline
\end{tabular}

Note. SE1, SE2 ... SE14 refer to the difference between the 14 paired satisfactions and expectations, respectively. 


\section{References}

1. Li, J. Impact of tourists' perceived value on brand loyalty: A case study of Xixi National Wetland Park. Asia Pac. J. Tour. Res. 2021, 26, 262-276. [CrossRef]

2. Chen, J.S.; Gursoy, D. Cross-cultural comparison of the information sources used by first-time and repeat travelers and its marketing implications. Hosp. Manag. 2000, 19, 191-203. [CrossRef]

3. Chi, C.G. An examination of destination loyalty: Differences between first-time and repeat visitors. J. Hosp. Tour. Res. 2012, 36, 3-24. [CrossRef]

4. Coskun, G. Investigating the relationship between values, satisfaction and intention to return: The case of Clemson International Food Festival. J. Tour. Manag. Res. 2018, 3, 1-13. [CrossRef]

5. Deng, J.; Andrada, R.; Pierskalla, C. Visitors' and residents' perceptions of urban forests for leisure in Washington D.C. Urban For. Urban Green. 2017, 28, 1-11. [CrossRef]

6. Petrick, J.F.; Sirakaya, E. Segmenting cruisers by loyalty. Ann. Tour. Res. 2004, 31, 472-475. [CrossRef]

7. Yuksel, A. Managing customer satisfaction and retention: A case of tourist destinations, Turkey. J. Vacat. Mark. 2001, 7, 153-168. [CrossRef]

8. Yoon, Y.; Usyal, M. An examination of the effects of motivation and satisfaction on destination loyalty: A structural model. Tour. Manag. 2005, 26, 45-56. [CrossRef]

9. LaTour, S.A.; Peat, N.C. Conceptual and methodological issues in consumer satisfaction research. Adv. Consum. Res. 1979, 6, 431-437.

10. Tanford, S. Antecedents and outcomes of hospitality loyalty: A meta-analysis. Cornell Hosp. Q. 2016, 57, 122-137. [CrossRef]

11. Baker, D.A.; Crompton, J.L. Quality, satisfaction and behavioral intentions. Ann. Tour. Res. 2000, 27, 785-804. [CrossRef]

12. Bigne, J.E.; Andreu, L.; Gnoth, J. The theme park experience: An analysis of pleasure, arousal and satisfaction. Tour. Manag. 2005, 26, 833-844. [CrossRef]

13. Demirgüneş, B.K. Relative importance of perceived value, satisfaction and perceived risk on willingness to pay more. Int. Rev. Manag. Mark. 2015, 5, 211-220.

14. Lopez-Mosquera, N.; Sanchez, M. Cognitive and affective determinants of satisfaction, willingness to pay, and loyalty in suburban parks. Urban For. Urban Green. 2014, 13, 375-384. [CrossRef]

15. Tang Bohu Entertainment. Four Destinations That Charge the Most, but Value for Money. Available online: https://www.163 com/dy/article/FT98M7640544P4TT.html (accessed on 12 July 2021).

16. Chi, C.G.; Qu, H. Examining the structural relationships of destination image, tourist satisfaction and destination loyalty: An integrated approach. Tour. Manag. 2008, 29, 624-636. [CrossRef]

17. Tang, Y. Travel motivation, destination image and visitor satisfaction of international tourists after the 2008 Wenchuan earthquake: A structural modelling approach. Asia Pac. J. Tour. Res. 2014, 19, 1260-1277. [CrossRef]

18. Li, X.; Cheng, C.K.; Kim, H.; Petrick, J.F. A systematic comparison of first-time and repeat visitors via a two-phase online survey. Tour. Manag. 2008, 29, 278-293. [CrossRef]

19. Kozak, M.; Bigne, E.; Andreu, L. Satisfaction and destination loyalty: A comparison between non-repeat and repeat tourists. J. Qual. Assur. Hosp. Tour. 2004, 5, 43-59. [CrossRef]

20. Mohr, K.; Backman, K.F.; Gahan, L.W.; Backman, S.J. An investigation of festival motivations and event satisfaction by visitor type. Fest. Manag. Event Tour. 1993, 1, 89-97. [CrossRef]

21. Huang, S.; Hsu, C.H.C. Effects of travel motivation, past experience, perceived constraints, and attitude on revisit intention. J. Travel Res. 2009, 48, 29-44. [CrossRef]

22. Yuan, J.; Morrison, A.M.; Cai, L.; Linton, S. A model of wine tourist behaviour: A festival approach. Int. J. Tour. Res. 2008, 10, 207-219. [CrossRef]

23. Anwar, S.A.; Sohail, M.S. Festival tourism in the United Arab Emirates: First-time versus repeat visitor perceptions. J. Vacat. Mark. 2004, 10, 161-170. [CrossRef]

24. McKercher, B.; Wong, D.Y.Y. Understanding tourism behaviour: Examining the combined effects of prior visitation history and destination status. J. Travel Res. 2004, 43, 171-179. [CrossRef]

25. Campo, S.; Garau-Vadell, J.B.; Martinez-Ruiz, M.P. Factors Influencing Repeat Visits to a Destination: The Influence of Group Composition. Tour. Manag. 2010, 31, 862-870. [CrossRef]

26. Sarra, A.; Di Zio, S.; Cappucci, M. A quantitative valuation of tourist experience in Lisbon. Ann. Tour. Res. 2015, 53, 1-16. [CrossRef]

27. Zeinali, B.; Jafarpour, M. Does visitors' demographics, status, length of stay, and travel party affect loyalty indicators? A case of visitors to El-Golu Park, Iran. Eur. J. Hosp. Tour. Res. 2015, 3, 24-40.

28. Wang, B.; Wu, C. A Systematic Comparison of First-Time and Repeat Visitors' Satisfaction with a Destination. Available online: https:/ / ieeexplore.ieee.org/document/4680205 (accessed on 20 June 2021).

29. Andersson, T.D. The tourist in the experience economy. Scand. J. Hosp. Tour. 2007, 7, 46-58. [CrossRef]

30. Choo, H.; Petrick, J.F. Comparison between first-timers and repeaters for relationship marketing implications. Int. J. Tour. Res. 2012, 14, 298-302. [CrossRef]

31. Liu, C.; Lin, W.; Wang, Y. Relationship between self-congruity and destination loyalty: Differences between first-time and repeat visitors. J. Destin. Mark. Manag. 2012, 1, 118-123. [CrossRef] 
32. Lv, X.; Li, C.; McCabe, S. Expanding theory of tourists' destination loyalty: The role of sensory impressions. Tour. Manag. 2020, 77, 104026. [CrossRef]

33. Lee, J.; Lee, C.; Yoon, Y. Investigating differences in antecedents to value between first-time and repeat festival-goers. J. Travel Tour. Mark. 2009, 26, 688-702. [CrossRef]

34. Pereda, M.H. Repeat Visitors of a Tourist Destination. Available online: https://www.semanticscholar.org/paper/REPEATVISITORS-OF-A-TOURIST-DESTINATION-Pereda/b34bb0c71a26efc6e49c0f46adadda07d692e96f (accessed on 20 June 2021).

35. Brida, J.G.; Pulina, M.; Riano, E.; Zapata-Aguirre, S. Cruise visitors' intention to return as land tourists and to recommend a visited destination. Anatolia Int. J. Tour. Hosp. Res. 2012, 23, 395-412. [CrossRef]

36. George, R. Tourist's perceptions of safety and security while visiting Cape Town. Tour. Manag. 2003, 24, 575-585. [CrossRef]

37. Sonmez, S.F.; Graefe, A.R. Determining future travel behaviour from past travel experience and perceptions of risk and safety. $J$. Travel Res. 1998, 37, 171-177. [CrossRef]

38. Crompton, J.L. Structure of vacation destination choice sets. Ann. Tour. Res. 1992, 19, 420-434. [CrossRef]

39. Hong, S.-k.; Lee, S.-W.; Lee, S.; Jang, H. Selecting revisited destinations. Ann. Tour. Res. 2009, 36, 268-294. [CrossRef]

40. Milman, A.; Pizam, A. The role of awareness and familiarity with a destination: The central Florida case. J. Travel Res. 1995, 33, 21-27. [CrossRef]

41. Weaver, P.A.; Weber, K.; McCleary, K.W. Destination evaluation: The role of pervious travel experience and trip characteristics. J. Travel Res. 2007, 45, 333-344. [CrossRef]

42. Iso-Ahola, S.E. Toward a social psychological theory of tourism motivation: A rejoinder. Ann. Tour. Res. 1982, 9, 256-262. [CrossRef]

43. Virden, R.J.; Knopf, R.C. Activities, experiences, and environmental settings: A case study of recreation opportunity spectrum relationships. Leis. Sci. 1989, 11, 159-176. [CrossRef]

44. Moutinho, L. Consumer behaviour in tourism. Eur. J. Mark. 1987, 21, 3-44. [CrossRef]

45. Mill, R.; Morrison, A. The Tourism System: An Introductory Text, 3rd ed.; Dendall/Hunt Publishing Company: Dubuque, IA, USA, 1998; ISBN 0787233277.

46. Cole, S.; Crompton, J. A conceptualization of the relationships between service quality and visitor satisfaction, and their links to destination selection. Leis. Stud. 2003, 22, 65-80. [CrossRef]

47. Albayrak, T.; Caber, M. Examining the relationship between tourist motivation and satisfaction by two competing methods. Tour. Manag. 2018, 69, 201-213. [CrossRef]

48. Hosany, S.; Buzova, D.; Sanz-Blas, S. The influence of place attachment, ad-evoked positive affect, and motivation on inten-tion to visit: Imagination proclivity as a moderator. J. Travel Res. 2020, 59, 477-495. [CrossRef]

49. Barbeitos, I.M.; Oom do Valle, P.; Guerreiro, M.; Mendes, J. Visitors' motivations, satisfaction and loyalty towards Castro Marim Medieval Fair. J. Spat. Organ. Dyn. 2014, 2, 89-104.

50. Langgat, J.; Marzuki, K.M.; Fabeil, N.F.; Dahnil, I. Visitor motivation, expectation and satisfaction of local cultural event in Sabah, A case study of Tamu Besar Kota Belud. Int. J. Cult. Tour. Res. 2012, 5, 48-59.

51. Battour, M.M.; Battor, M.M.; Ismail, M. The mediating role of tourist satisfaction: A study of Muslim tourists in Malaysia. J. Travel Tour. Mark. 2012, 29, 279-297. [CrossRef]

52. Homburg, C.; Koschate, N.; Hoyer, W.D. Do satisfied customers really pay more? A study of the relationship between customer satisfaction and willingness to pay. J. Mark. 2005, 69, 84-96. [CrossRef]

53. Baral, N.; Stern, M.J.; Bhattarai, R. Contingent valuation of ecotourism in Annapurna conservation area, Nepal: Implications for sustainable park finance and local development. Ecol. Econ. 2008, 66, 218-227. [CrossRef]

54. Disegna, M.; Osti, L. Tourists' expenditure behaviour: The influence of satisfaction and the dependence of spending categories. Tour. Econ. 2016, 22, 5-30. [CrossRef]

55. Zhang, L.; Qu, H.; Ma, J. Examining the relationship of exhibition attendees' satisfaction and expenditure: The case of two major exhibitions in China. J. Conv. Event Tour. 2010, 11, 100-118. [CrossRef]

56. Dean, A.; Morgan, D.; Tang, T.E. Service quality and customers' willingness to pay more for travel services. J. Travel Tour. Mark. 2002, 12, 95-110. [CrossRef]

57. Parasuraman, A.; Berry, L.L.; Zeithaml, V.A. Refinement and reassessment of the SERVQUAL scale. J. Retail. 1991, 67, 420-450.

58. Anderson, E.W.; Fornell, C.; Lehmann, D.R. Customer satisfaction, market share, and profitability: Findings from Sweden. J. Mark. 1994, 58, 53-66. [CrossRef]

59. Oliver, R.L. Cognitive, affective, and attribute bases of the satisfaction response. J. Consum. Res. 1993, 20, 418-430. [CrossRef]

60. Spreng, R.A.; Mackenzie, S.B.; Olshavsky, R.W. A Reexamination of the Determinants of Consumer Satisfaction. J. Mark. 1996, 60, 15-32. [CrossRef]

61. Pinto, P.; Silva, J.A.; Mendes, J.; Guerreiro, M. Tourist Satisfaction and Destination Loyalty intention: A Structural and Categorical Analysis. Int. J. Bus. Sci. Appl. Manag. 2006, 1, 25-44.

62. Yüksel, A.; Yüksel, F. The expectancy-disconfirmation paradigm: A critique. J. Hosp. Tour. Res. 2001, 25, 107-131. [CrossRef]

63. Driver, B.L. Item Pool for Scales Designed to Quantify the Psychological Outcomes Desired and Expected from Recreation Participation; USDA Forest Service Rocky Mountain Forest \& Range Experiment Station: Fort Collins, CO, USA, 1977.

64. Arana, J.E.; Leon, C.J. Correcting for scale perception bias in tourism satisfaction surveys. J. Travel Res. 2013, 52, 772-788. [CrossRef] 
65. Park, S.; Hahn, S.; Lee, T.; Jun, M. Two factor model of consumer satisfaction: International tourism research. Tour. Manag. 2018, 67, 82-88. [CrossRef]

66. Baloglu, S.; Pekcan, A.; Chen, S.L.; Santos, J. The relationship between destination performance, overall satisfaction, and behavioural intention for distinct segments. J. Qual. Assu. Hosp. Tour. 2003, 4, 149-165. [CrossRef]

67. Bigne, J.E.; Sanchez, M.I.; Sanchez, J. Tourism image, evaluation variables and after-purchase behaviour: Inter-relationship. Tour Manag. 2001, 22, 607-616. [CrossRef]

68. Raggiotto, F.; Scarpi, D. This must be the place: A destination-loyalty model for extreme sporting events. Tour. Manag. 2021, 83, 104254. [CrossRef]

69. Oppermann, M. Tourism destination loyalty. J. Travel Res. 2000, 39, 78-84. [CrossRef]

70. Luo, Y.; Deng, J. The New Environmental Paradigm and nature-based tourism motivation. J. Travel Res. 2008, 46, 392-402. [CrossRef]

71. Wu, C.; Deng, J.; Li, S. Economic evaluation for recreation benefits of Zhangjiajie National Forest Park. Sci. Silvae Sin. 1992, 28, 423-430.

72. Parsons, E.C.M.; Warburton, C.A.; Woods-Ballard, A.; Hughes, A.; Johnston, P.; Bates, H.; Luck, M. Whale-watching tourists in West Scotland. J. Ecotour. 2003, 2, 93-113. [CrossRef]

73. Schafer, J.L. Multiple imputation: A primer. Stat. Methods Med. Res. 1999, 8, 3-15. [CrossRef] [PubMed]

74. Veen, R.V.D.; Song, H. Impact of the perceived image of celebrity endorsers on tourists' intentions to visit. J. Travel Res. 2013, 53, 211-224. [CrossRef]

75. Kline, R.B. Principles and Practice of Structural Equation Modeling, 2nd ed.; Guilford Press: New York, NY, USA, 2005; ISBN 1572306904.

76. Song, Z.; Xing, L.; Chathoth, P.K. The effects of festival impacts on support intentions based on residents' ratings of festival performance and satisfaction: A new integrative approach. J. Sustain. Tour. 2015, 23, 316-337. [CrossRef]

77. Comrey, A.; Lee, H. A First Course in Factor Analysis, 2nd ed.; Lawrence Erlbaum Associates: Hillsdale, NJ, USA, 1992; ISBN 0805810625.

78. Hair, J.F.; Black, W.C.; Babin, B.J.; Anderson, R.E. Multivariate Data Analysis, 7th ed.; Prentice Hall: Upper Saddle River, NJ, USA, 2010; ISBN 0138132631.

79. Deng, J.; Walker, G.J.; Swinnerton, G. Comparison of environmental values and attitudes between Chinese in Canada and Anglo-Canadians. Environ. Behav. 2006, 38, 22-47. [CrossRef]

80. Hasegawa, T.; Gudykunst, W.B. Silence in Japan and the United States. J. Cross Cult. Psychol. 1998, 29, 668-685. [CrossRef]

81. Nunnally, J.C. Psychometric Theory, 3rd ed.; McGraw-Hill: New York, NY, USA, 1994; ISBN 007047849X.

82. Anderson, J.C.; Gerbing, D.W. Structural equation modeling in practice: A review and recommended two-step approach. Psychol. Bull. 1988, 103, 411-423. [CrossRef]

83. Fornell, C.; Larcker, D.F. Evaluating structural equation models with unobserved variables and measurement error. J. Mark. Res. 1981, 18, 39-50. [CrossRef]

84. Wheaton, B.; Muthén, B.; Alwin, D.F.; Summers, G.F. Assessing reliability and stability in panel models. In Sociological Methodology, 1st ed.; Heise, D.R., Ed.; Jossey-Bass: San Francisco, CA, USA, 1977; pp. 84-136. ISBN 978087589286.

85. MacCallum, R.C.; Browne, M.W.; Sugawara, H.M. Power analysis and determination of sample size for covariance structure modeling. Psychol. Methods 1996, 1, 130-149. [CrossRef]

86. Hooper, D.; Coughlan, J.; Mullen, M.R. Structural equation modelling: Guidelines for determining model fit. Electron. J. Bus. Res. Methods 2008, 6, 53-60.

87. Bollen, K.A. Structural Equations with Latent Variables; Wiley: New York, NY, USA, 1989; ISBN 978-0-471-01171-2.

88. Hsu, C.H.C.; Cai, L.A.; Li, M. Expectation, motivation, and attitude: A tourist behavioral model. J. Travel Res. 2010, 49, 282-296. [CrossRef]

89. Kim, H.; Ku, B.; Kim, J.Y.; Park, Y.J.; Park, Y.B. Confirmatory and exploratory factor analysis for validating the Phlegm Pattern Questionnaire for healthy subjects. Evid. Based Complement. Alternat. Med. 2016, 2016, 2696019. [CrossRef]

90. Marques, C.; da Silva, R.V.; Antova, S. Image, satisfaction, destination and product post-visit behaviours: How do they relate in emerging destinations? Tour. Manag. 2021, 85, 104293. [CrossRef]

91. Schofield, P.; Thompson, K. Visitor motivation, satisfaction and behavioural intention: The 2005 Naadam Festival, Ulaanbaatar. Int. J. Tour. Res. 2007, 9, 329-344. [CrossRef]

92. Shang, X.; Luo, F.; Shi, D. Research on the influence of forest park tourism image on tourist behaviour intention based on tourist satisfaction-Take Zhangjiajie national forest park as an example. J. Cent. South Univ. For. Techol. (Soc. Sci.) 2017, 11, 58-62.

93. Oliver, R.L. A cognitive model of the antecedents and consequences of satisfaction decisions. J. Mark. Res. 1980, 17, 460-469. [CrossRef]

94. Festinger, L. A theory of social comparison processes. Hum. Relat. 1954, 7, 117-140. [CrossRef]

95. Ball, R.; Chernova, K. Absolute income, relative income, and happiness. Soc. Indic. Res. 2008, 88, 497-529. [CrossRef]

96. Huang, J.; Wu, S.; Deng, S. Relative income, relative assets, and happiness in urban China. Soc. Indic. Res. 2016, 126, 971-985. [CrossRef]

97. Knight, J.; Song, L.; Gunatilaka, R. Subjective well-being and its determinants in rural China. China Econ. Rev. 2009, 20, 635-649. [CrossRef] 
98. Oshio, T.; Nozaki, K.; Kobayashi, M. Relative income and happiness in Asia: Evidence from nationwide surveys in China, Japan, and Korea. Soc. Indic. Res. 2010, 104, 351-367. [CrossRef]

99. Woodruff, R.B.; Cadotte, E.R.; Jenkins, R.L. Modeling consumer satisfaction processes using experience-based norms. J. Mark. Res. 1983, 20, 296-304. [CrossRef]

100. Halstead, D. The use of comparison standards in customer satisfaction research and management: A review and proposed typology. J. Mark. Theory Pract. 1999, 7, 13-26. [CrossRef]

101. Koufteros, X.; Babbar, S.; Kaighobadi, M. A paradigm for examining second-order factor models employing structural equation modeling. Int. J. Prod. Econ. 2009, 120, 633-652. [CrossRef]

102. Chinese News. Critique on Ticket Economy: Entrance Fee for Scenic Areas over $¥ 100$ Is too Much. Available online: https:/ / baike.baidu.com/reference/4944404/df2fJDDSrEmXholLVGlO9J5ja6VghOeO4csZ1_4r9I6oCbKLbR9o4D_8-rebX1oQLD3 5FHp8ETQQktm_Wtcd2SN-wVcKeMIISFhJSMl2ues (accessed on 20 June 2021). 